
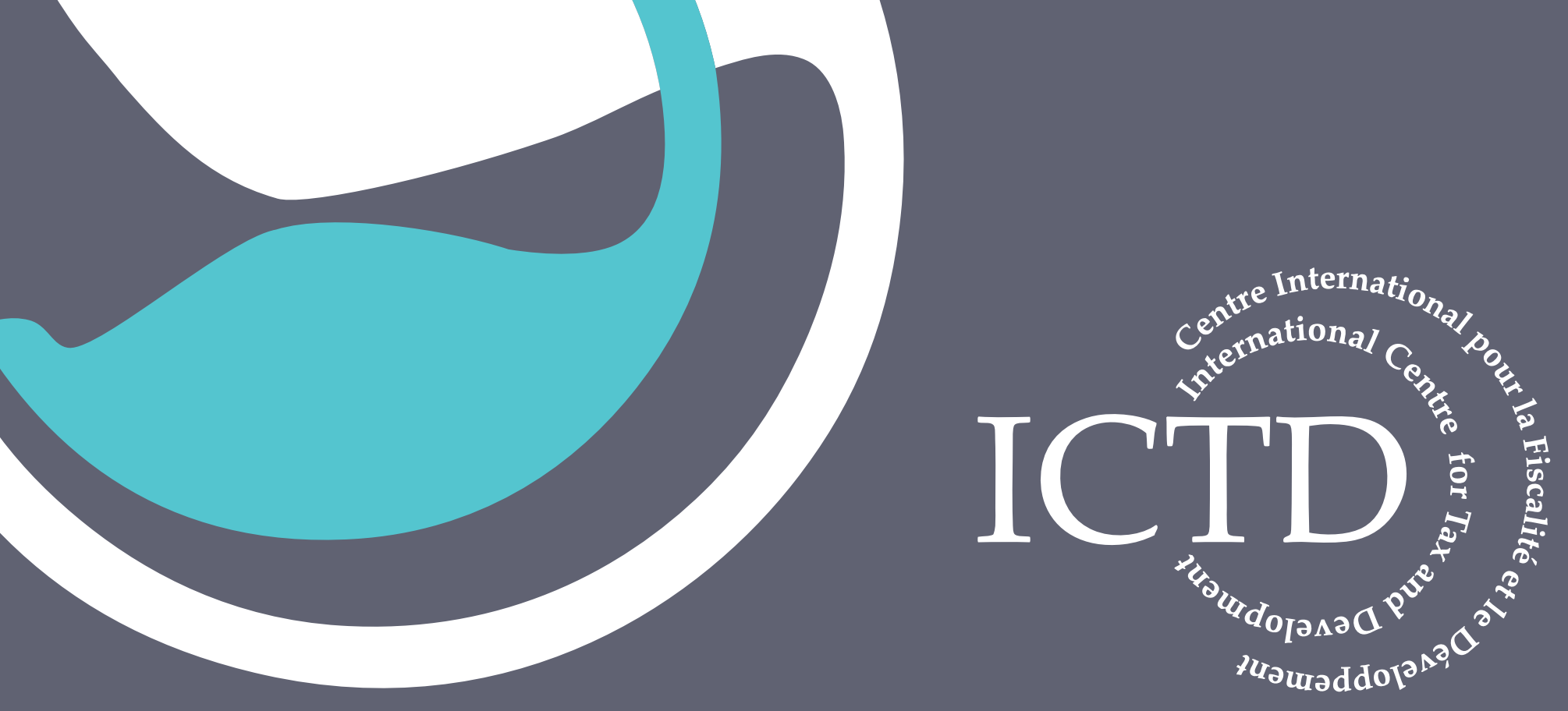

Working Paper 63

\title{
Transfer Pricing in Argentina 1932-2015
}

Veronica Grondona and Andres Knobel January 2017 
ICTD Working Paper 63

\section{Transfer Pricing in Argentina 1932-2015}

Veronica Grondona and Andres Knobel

January 2017 
Transfer Pricing in Argentina 1932-2015

Veronica Grondona and Andres Knobel

ICTD Working Paper 63

First published by the Institute of Development Studies in January 2017

(C) Institute of Development Studies 2017

ISBN: 978-1-78118-345-8

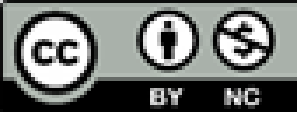

This is an Open Access paper distributed under the terms of the Creative Commons Attribution Non Commercial 4.0 Internationa license, which permits downloading and sharing provided the original authors and source are credited - but the work is not used for commercial purposes. http://creativecommons.org/licenses/by-nc/4.0/legalcode

Available from:

The International Centre for Tax and Development at the Institute of Development Studies, Brighton BN1 9RE, UK

Tel: +44 (0) 127360626

Email: info@ictd.ac.uk

Web: www.ictd/en/publications

IDS is a charitable company limited by guarantee and registered in England

Charity Registration Number 306371

Charitable Company Number 877338 


\title{
Transfer Pricing in Argentina 1932-2015
}

\author{
Veronica Grondona with Andres Knobel
}

\begin{abstract}
Summary
This document provides a review of the Argentine tax authority's structure for dealing with transfer pricing in Argentina; a chronological review of the legislative transfer pricing framework; and a very extensive listing of the transfer pricing cases that have reached different court levels. The document also summarises some of the difficulties encountered in relation to the application of the arm's length principle in Argentina; coordination with foreign tax authorities; and the regulatory changes expected following the reports resulting from the G20/OECD BEPS Action Plan. Argentine transfer pricing legislation has taken several turns over time, moving from a more restrictive pricing of exports and imports for income tax purposes to what is today internationally known as the Sixth Method for commodity valuation; and from an application of what is locally known as the 'economic reality' principle, a principle attempting to consider the economic substance over the contractual forms, to a transplantation into local legislation of the Organisation for Economic Co-operation and Development's Transfer Pricing Guidelines based on the arm's length principle. The consequences of these regulatory changes have been that lately more and more cases are being disputed at different court levels, and tax authorities seem to find it increasingly difficult to challenge multinational entities' transfer pricing manipulation schemes and support their arguments in courts of law.
\end{abstract}

Keywords: transfer pricing, Argentina, Sixth Method, arm's length, BEPS Action Plan.

Veronica Grondona is an Argentinean researcher at the Cultural Centre for Cooperation Floreal Gorini (in Spanish, Centro Cultural de la Cooperación, CCC). She graduated in economics (University of Buenos Aires, 2000), with postgraduate studies in finance (Universidad Torcuato Di Tella, 2003). Some of her main research interests relate to transfer pricing manipulation, base erosion and capital flight.

Andres Knobel is a lawyer and consultant with the Tax Justice Network, focusing on tax havens and automatic exchange of information. 


\section{Contents}

Summary $\quad 3$

Acknowledgements $\quad 5$

Acronyms $\quad 5$

Introduction $\quad 6$

1 Tax administration resources dedicated to international tax and transfer pricing

2 Legal framework and court decisions 10

2.1 An early focus on the pricing of commodity exports (1932-1961) 10

2.2 The application of the economic reality principle (1961-1976) 11 2.2.1 The pricing of imported and exported goods during this period 12

2.3 The shift to the independent entity principle (under the dictatorship) (1976-1983) and the restoration of democracy (1983-1998) 13

2.3.1 The pricing of imported and exported goods during this period $\quad 14$

2.4 The introduction of the OECD Transfer Pricing Guidelines (1998-today) and the refinement of the 1976 approach 14

2.4.1 Transfer pricing litigation in this period 16

2.4.2 Introduction of the Sixth Method for the pricing

of commodity exports

3 Problems with the arm's length principle 18

3.1 Difficulties with the application of the arm's length principle 18

3.2 Solutions implemented by the AFIP to improve the effectiveness of transfer pricing audits

3.3 Measuring the effectiveness of transfer pricing audits 23

4 Coordination with foreign tax authorities 25

5 Regulatory changes relating to the G20/OECD BEPS Action Plan 27

6 Conclusions $\quad 29$

Appendices

Appendix $1 \quad$ Summary table with transfer pricing-related court decisions $\quad 31$

Appendix 2 Information currently being requested in relation to transfer pricing 39

$\begin{array}{lll}\text { Appendix } 3 & \text { Interviews held } & 40\end{array}$

$\begin{array}{ll}\text { References } & 41\end{array}$

Tables

Table 1 Spontaneous adjustment to the tax base and income tax based on transfer pricing declarations

Table 2 Spontaneous adjustment to the tax base and income tax, as a consequence of adjustments to the price of commodities

Table 3 Various triangulation situations found by the AFIP since 2009

Figures

Figure 1 Organisational structure of the Sub General Directorate of Tax Auditing - Federal Administration of Public Revenue (AFIP)

Figure 1 TP audits by economic sector (taxpayers audited 2009) 


\section{Acknowledgements}

We would like to thank Sol Picciotto for the guidance provided during the elaboration of this document; and Artistides Corti for assistance in the interpretation of the Argentine legislative changes and court cases.

\section{Acronyms}

AAEF Asociación Argentina de Estudios Fiscales (Argentine Association of

AFIP Administración Federal de Ingresos Públicos (Federal Administration of Public Revenue)

APA Advance Pricing Agreement

BEPS Base erosion and profit shifting

$\mathrm{CbC} \quad$ Country-by-country

CCAF Cámara Nacional de Apelaciones en lo Contencioso Administrativo

Federal (National Federal Administrative Litigation Appeal Chamber)

CIAT Inter-American Centre of Tax Administrations

CIF Carriage, insurance and freight

CSJN Corte Suprema de Justicia (National Supreme Court of Justice)

CUP Comparable Uncontrolled Price

DTT Double Tax Treaty

IGJ Inspección General de Justicia (General Justice Inspectorate)

LIG Ley de Impuesto a las Ganancias (Income Tax Law)

MAP Mutual Agreement Procedure

MERCOSUR Mercado Común del Sur (Common Market of the South)

MNE Multinational entities

OECD Organisation for Economic Co-operation and Development

TFN Tribunal Fiscal de la Nación (National Tax Court)

TIEA Tax Information Exchange Agreements

TNMM Transactional Net Margin Method 


\section{Introduction}

This paper aims to provide an overview of the legal, institutional and administrative arrangements for dealing with transfer pricing in Argentina.

Argentine transfer pricing legislation has taken several turns over time, moving from a more restrictive pricing of exports and imports for income tax purposes to what is today internationally known as the Sixth Method for commodity valuation; and from an application of what is locally known as the 'economic reality' principle, a principle attempting to consider the reality of the activities (the economic substance) over the contractual forms, to a transplantation into local legislation of the Organisation for Economic Co-operation and Development (OECD)'s Transfer Pricing Guidelines based on the arm's length principle.

Some of the legislative changes for some time were based on court interpretations of the complexities of valuing intragroup transactions. However, the contradictions and incoherence caused by the introduction of the arm's length criteria into local rules have meant that in recent years there have been no court rulings to create precedents, contributing to a system which is not clear either for the taxpayers or the tax authorities.

However, although the tax authorities have had several problems when attempting to use the arm's length criteria, they do not openly question the appropriateness of the OECD methodology.

In the context of the current concerns about base erosion and profit shifting (BEPS), it is hoped that the experience of a mid-level developing country and G20 member could be instructive.

This study is based on a combination of documentary research and information from practitioners, especially revenue authorities, and is structured as follows. Section 1 outlines the tax administration resources devoted to international tax and transfer pricing; Section 2 discusses the legal framework as it has developed through both legislation and court cases relating to transfer pricing; Section 3 summarises some of the difficulties encountered in relation to the application of the arm's length principle in Argentina and the solutions implemented by the revenue authority, the Federal Administration of Public Revenue (AFIP), to improve the effectiveness of transfer pricing audits; Section 4 outlines coordination with foreign tax authorities; Section 5 discusses the regulatory changes expected following the reports resulting from the G20/OECD BEPS Action Plan; and Section 6 presents some brief conclusions extracted from this paper. Appendix 1 provides a complete summary table of transfer pricing-related court cases; Appendix 2 briefly describes Argentina's current transfer pricing documentation requirements; and Appendix 3 lists the people interviewed in the research for this report. References are listed at the end of the report. 


\section{Tax administration resources dedicated to international tax and transfer pricing ${ }^{1}$}

Until 2010, activities performed in relation to international tax were dispersed in several offices, such as the Sub General Directorate of Planning, the Sub General Directorate of Technical-Institutional Coordination, and the Sub General Directorate of Tax Collection. ${ }^{2}$

The International Tax Auditing department of the Central Government in Argentina was created in 2010, and in 2015 had $35^{3}$ staff dedicated to transfer pricing and international tax issues under the following organisational structure.

\section{Figure 2 Organisational structure of the Sub General Directorate of Tax Auditing - Federal Administration of Public Revenue (AFIP)}

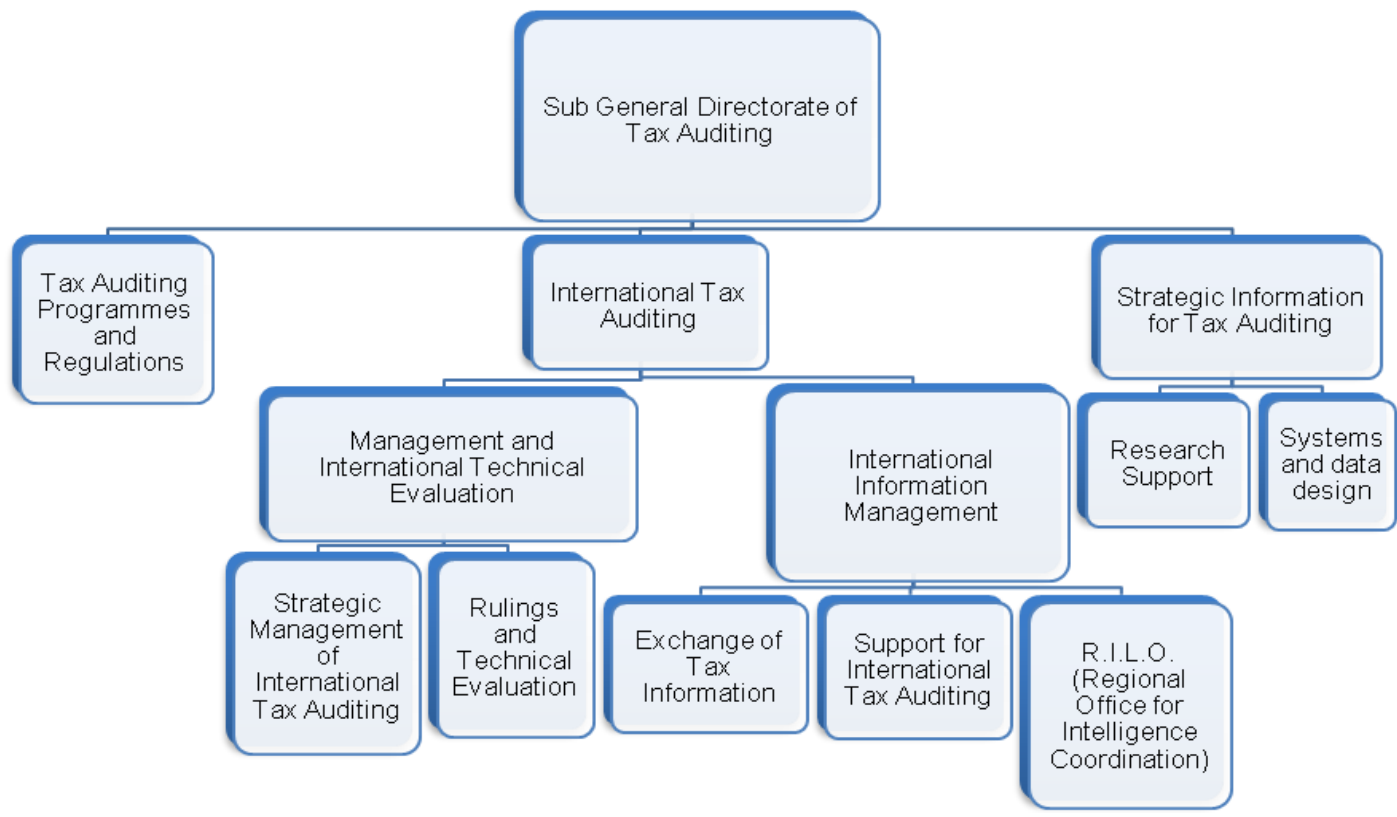

Source: Disposition 19/2010 Organisational Structure. Modified on 25 January 2010; updated after interview with AFIP representatives (See Section 8).

The AFIP is responsible, under powers delegated by the Ministry for the Economy (Resolution 336/2003), for the application of domestic tax law relating to international

This section incorporates significant parts of La manipulación de los precios de transferencia Argentina, Fuga de Capitales IV, CEFID-AR Working Paper 58, written by Veronica Grondona under the supervision of Jorge Gaggero (Coordinator of the Capital Flight Programme at CEFID-AR) and published by the Centre of

Economy and Finance for Development in Argentina (Centro de Economía y Finanzas para el Desarrollo de la Argentina) (CEFID-AR) in June 2014; and in collaboration with the Systems of Tax Evasion And Laundering (STEAL) project (\#212210) of the Research Council of Norway (NUPI). The complete document is available at www.cefid-ar.org.ar/documentos/Fuga_de_capitales_IV_web.pdf (accessed 16 November 2016). For a short English version see Grondona 2015.

Decree 898/2005.

As will be described below, these 35 people do not have tax auditing functions, but design the auditing strategies. 
transactions as well as double tax treaties (DTTs) and information exchange in tax matters. Since 2011, a Joint Commission of the Ministry for the Economy, AFIP and the Ministry of Foreign Affairs has been reviewing the double tax treaties in place. It was understood that such treaties required an integrated analysis combining economic, political and fiscal aspects. ${ }^{4}$

The reason for this review was that Argentina had signed most of its tax treaties during the 1970s, 1980s and 1990s and, as explained in the Resolution, the international context at that time was different to the current one. As an importer of capital, Argentina needed to evaluate the fiscal sacrifice that such tax treaties implied. ${ }^{5}$

Departments which come under the Sub General Directorate of Tax Auditing include (i) the Directorate of Tax Auditing Programmes and Regulation, which manages the technological aspects of tax audits; and (ii) the International Tax Auditing Directorate, responsible for analysing economic sectors, detecting risk zones for tax control in relation to transfer pricing and other international tax issues; and strategic research to support tax audits. The latter includes a section for Strategic Management of International Tax Auditing, which is in charge of transfer pricing and intelligence, and is where the preliminary research stages are performed. It does not have tax auditing functions, but analyses digital information in order to elaborate tax audit strategies, by sector or topic (including the application of the Sixth Method to commodity export pricing, and intangibles).This system formulates a National Annual Auditing Plan to be applied through the Tax Auditing Monitoring System (SSeFI).

Audit planning has been facilitated by the digital filing of documentation, ${ }^{6}$ including statutory accounts, transfer pricing declarations, information on independent parties in some cases, and customs and immigration information.

Since 2000, the AFIP has examined transfer pricing (i) during the course of general tax audits; (ii) during specific transfer pricing audits in industries previously identified based on the documentation and declarations presented by the companies (e.g. automotive, pharmaceutical, iron and steel, fishing, cereals, oil); (iii) of companies with operations in tax havens; ${ }^{7}$ and (iv) of companies that have registered technology transfer or brand licensing agreements with the National Institute of Industrial Property. ${ }^{8}$

According to Echegaray, Michel and Barzola (2013), transfer pricing audits have been conducted in the following economic sectors.

\footnotetext{
In 2004, the Internal Revenue Secretariat of the Ministry of Economy (a secretariat which is organically different from the AFIP) incorporated among its objectives the supervision of the negotiation of international agreements relating to tax and customs.

Following this resolution, Argentina cancelled its treaties with Spain, Chile and Switzerland, and negotiated new treaties with these jurisdictions, as well as with others such as Germany.

Appendix 2 provides a brief description of local transfer pricing documentation requirements.

Decree 1037/2000 listed the 88 domains, jurisdictions and associated states and special tax regimes that are considered as 'countries of zero or low taxes'. However, jurisdictions establishing a Tax Information Exchange Agreement (TIEA) with Argentina could be excluded from the list. In May 2013, Decree 589 replaced this article with a positive list of cooperative jurisdictions for the purpose of tax transparency, comprising countries signing or negotiating a TIEA or a DTT. This list is available at

www.afip.gov.ar/genericos/novedades/jurisdiccionesCooperantes.asp (accessed 16 November 2016).

$8 \quad$ The following legislation relates to the registration of technology transfer contracts: Law 22.426; Decree 580; Law on foreign investment 21.382, modified by laws 23.697 and 23.760; and text organised by Decree 1853/93, in particular, Articles 7 and 8. Laws 24.481 and 24.572, text organised by Decree 260/96. Law 23.760, Articles 91, 92 and 93 (Inc. A) Decree 2353/86, Articles 156, 157 and 158.
} 
Figure 3 TP audits by economic sector (taxpayers audited 2009)

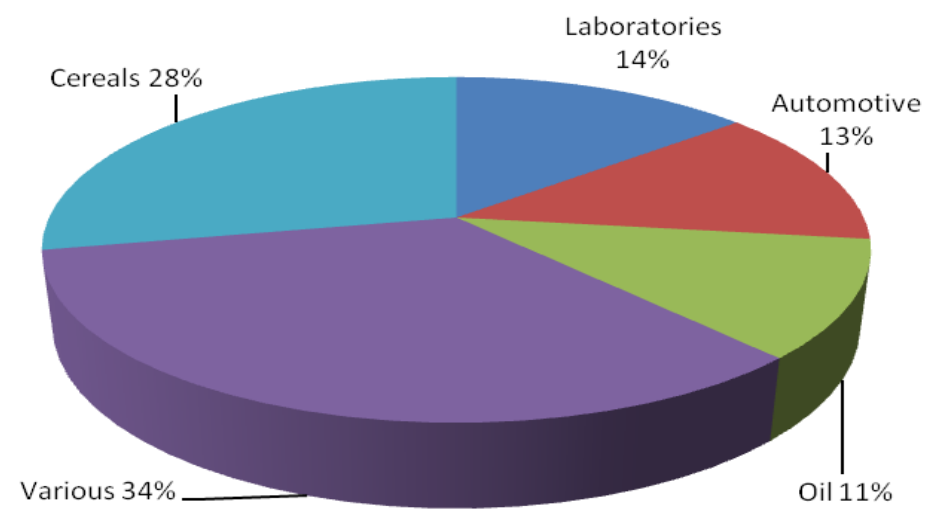

Source: Echegaray, Michel and Barzola, 2013: 111.

For customs information, the INDIRA ${ }^{9}$ system gives AFIP access to micro data (volumes, prices, invoicing details, etc.) from Argentina and other MERCOSUR countries, as well as some others, such as India. An agreement has recently been signed with the United States, and one with India previously, for sharing customs information, although not through the INDIRA database, since it is restricted to a bilateral exchange. However, customs data does not distinguish between related and unrelated parties. Customs micro data in this system - which works like an online database - can be accessed immediately and automatically by tax officials from the Sub General Directorate of Tax Auditing of the central administration. Where, for example, mismatches have been found, they send the relevant individual transaction data that have been screened by the central administration to the regional agency conducting the audit. Regional agencies cannot directly access the information.

As the number of audits has increased, ${ }^{10}$ the transactions examined have included not only the export and import of goods, but also intercompany debt, fees for technical services, commission payments, royalty payments, transfers of intangible property, and management fees (PwC 2012).

Audits are performed by the operative local regional agencies based on the tax audit strategy designed by the Sub General Directorate of Tax Auditing in the central administration, although these agencies can also act independently and choose auditing cases individually based on local parameters. The operative area of AFIP has three sub directorates under which the local regional agencies are grouped: 'Interior', 'Metropolitan' and 'Large Taxpayers'. In 'Interior' and 'Metropolitan' there are several regional directorates which perform transfer pricing audits, amongst other work, which have received continuous training since the year 2000. The Large Taxpayers unit, which is considered to be the most relevant one for transfer pricing purposes, has 25 people, including inspectors and supervisors, exclusively dedicated to transfer pricing. These 25 people are dedicated to auditing functions, while the 35 people working in the central Sub General Directorate of Tax Auditing design the auditing strategies.

INDIRA is a computer system implemented by the Mercado Común del Sur (MERCOSUR) through which customs administrations exchange information through an online database.

The CIAT transfer pricing report (CIAT 2013) stated that Argentina had carried out 3,500 transfer pricing audits in 2012. AFIP did not provide any information on the evolution of such transfer pricing audits. 


\section{Legal framework and court decisions ${ }^{11}$}

Tax decisions, including transfer pricing-related rulings, once the administrative process is complete, can be challenged legally at three levels (in ascending order): the National Tax Court (TFN); the National Federal Administrative Litigation Appeal Chamber (CCAF); and the National Supreme Court of Justice (CSJN).

According to the information provided by AFIP to the Inter-American Centre of Tax Administrations (CIAT) for their 2013 report (CIAT 2013), at the time of that report there were 29 pending transfer pricing cases at different court levels.

The analysis of transfer pricing legal framework and disputes can be divided into four phases or periods:

- an early focus on the pricing of commodity exports (1932-1961);

- the application of the economic reality principle (1961-1976);

- the shift to the independent entity principle, under the dictatorship (1976-1983), and after the restoration of democracy (1983-1998);

- the introduction of the OECD Transfer Pricing Guidelines (1998-today) and the refinement of the 1976 approach.

\subsection{An early focus on the pricing of commodity exports (1932-1961)}

The basic legal principle dating back to 1932 stated that: 'For the purposes of the present law income (profit) recorded in the territory of Argentina is presumed to have been obtained in Argentina, except when proved otherwise. ${ }^{.12}$ However, the determination of such income was found to be a problem.

The Vestey case was one of the export cases publicised by a Senate commission created in 1934 to analyse the consequences of the Roca-Runciman pact ${ }^{13}$ between Argentina and the United Kingdom (UK). The Commission's report revealed that the Anglo-Argentinean meat-packing company (Vestey) ${ }^{14}$ was paying no taxes in Argentina or in the UK. Senator De la Torre then suggested, in a public speech in the Congress, that for the purposes of calculating the income attributable to Argentina, the transaction prices should be based on the meat prices in the UK (CIF) ${ }^{15}$ less the cost of transportation and insurance calculated by the Argentine government. This was considered as a possible solution to the problem because it had been observed that the import price in the UK was significantly higher than the export price in Argentina.

In 1943 a decree introduced an article in the Income Tax Law for the determination of income that was thereafter known as the import and export clause. This clause (Article 7 of Decree 18.229/1943) required that the value of exported goods, for the purpose of the determination of income, should be established '(...) subtracting from the wholesale price at destination the cost of such goods, transport and insurance expenses, sales commissions and expenses, and other expenses incurred in Argentina'; while the value of imported goods should be determined based on the wholesale price at origin plus

Appendix 1 includes a complete listing of the transfer pricing-related cases that have reached different court levels, some of which are described or referenced in this section.

Article 17 of Law 11.682, Income Tax Law (Ley de Impuesto a los Réditos), consolidated in 1932 by Decree 112.578, paragraph 6 .

According to the Roca-Runciman pact, the UK agreed to keep buying Argentine meat, as long as its price was lower than that of other suppliers.

For a colourful account of the history of this company, and its tax avoidance, see Knightley 1993

$\mathrm{CIF}$ is the price at destination including the costs of carriage, insurance and freight (CIF). 
transport and insurance costs to Argentina. Also, the export and import clause indicated that a difference between the wholesale price at destination (less transport and insurance costs) and the price declared by the exporter would be understood as attributable to an economic relationship between the Argentine exporter and the importer from abroad, and any resulting income would be considered to be of Argentine source. The same treatment would be applied to differences between the import price and the wholesale price at origin (plus transport and insurance costs to Argentina). ${ }^{16}$

In cases where a wholesale price was not available, an arm's length principle would be applied; i.e. a comparison with the profits of independent entities ${ }^{17}$ could be used for the calculation of the profits of Argentine source.

In 1946, the export and import clause was amended in order to clarify the conditions under which the comparison with independent entities could be made when a wholesale price at origin was not available. ${ }^{18}$ In addition, Article 14 was introduced in the Income Tax Law determining that the net income of the branches and affiliates should be calculated based on separate accounting records; but if such accounts were inadequate, the tax authority could, for tax purposes, consider that the affiliate or branch and the parent company, are part of the same economic unit.

This Article 14 of the Income Tax Law was implemented by Article 15 of the Reglementary Decree 10.439/1947, which provided that when the separate accounts did not provide an easy and clear statement of the income from the activities within the country, then the net income of Argentine source should be determined based on the highest profits obtained by independent enterprises performing identical or similar activities.

\subsection{The application of the economic reality principle (1961-1976)}

The economic reality principle was first introduced into Argentine law in 1946, and is still quoted in the Federal Act on Tax Procedures, which provides that it should be the true substance of a taxable event and not the legal forms or structures used that need to be considered for the determination of the taxable base. ${ }^{19}$

However, such criteria were not applied to transfer pricing cases until 1961, when the tax court ruled in the case of Refinerías de Maíz. The case was brought to the CSJN, and on 10 June 1964, the CSJN ruled that royalty payments should be considered contributions to the income of the parent company (deemed dividends) and could not be deducted for income tax calculation purposes, since the parent company owned 96 per cent of the stocks of the Argentine affiliate, and hence such enterprises could not

The first ruling applying the import and export clause was that issued by the CSJN in 1967 in relation to SIA S.A. (See Appendix 1.)

17 One of the problems of the application of this criteria at the time was that it had not been clarified what was meant by a 'comparison with the profits of independent entities'.

$8 \quad$ Decree 14.338/1946 amending the last paragraph of Article 9 of Law 11.682 (Income Tax Law) reads: 'In cases where, in accordance with the preceding provisions, the wholesale price at the place of origin must be applied but it is not publicly and commonly known, or where there are doubts about whether it refers to the same goods as imported or to similar ones, or where comparison is difficult due to other reasons, the calculation of income sourced in Argentina shall be made on the basis of the percentage of profit obtained by independent enterprises engaged in identical or similar activities. In the absence of an identical or similar activity, the tax authority is hereby empowered to apply the net percentage that it establishes on the basis of branches of trade that have certain analogies to the one under consideration.' (As translated by Baistrocchi 2012.)

In July 1998, the Federal Act on Tax Procedures (Ley de Procedimiento Tributario, No. 11.683), which had originally been passed in 1932, and consolidated in 1978, was consolidated to incorporate the modifications that had been made to it over time. This Act specifies, in its first two articles, that for the interpretation of tax regulations their ultimate purpose and economic significance should be considered; hence it establishes the pre-eminence of the economic intention over the legal structures chosen by the taxpayer (Rua 2014). 
be considered to be independent. The underlying argument was the economic reality principle.

The CSJN applied this economic reality principle in several other cases relating to interest loan and royalty payments, and even merchandise transactions within the domestic market, in 1973 and $1974 .{ }^{20}$ The most notorious case was that of Parke Davis (1973). This decision created a strong precedent because the CSJN took the view that due simply to the financial relationships between related parties there was a lack of real independence. This had evident implications for the lack of freedom to choose the contractual terms and even the real income that such terms would produce, and also with respect to the need to contract with its related parties instead of with other non-related parties.

Between 1973 and 1974, Law 20.628 on income tax (hereinafter 'LIG', for its Spanish acronym), ${ }^{21}$ Law 20.557 on foreign capital investment, and Law 20.794 on technology transfer were enacted, establishing the legal doctrine which arose out of these rulings of the CSJN, ${ }^{22}$ which had determined that it was the substance (the 'economic reality') and not the legal form which was relevant, and that in view of this it was valid to disregard contractual arrangements between entities belonging to the same economic group. This doctrine stressed that such contracts had not been made between legally independent parties, either for operations within a country or with entities located abroad. ${ }^{23}$ Thus, the more detailed rules ${ }^{24}$ provided that fees for royalties, financial or technological services rendered to a foreign entity resident in the country by an economically-related company would not be deductible from the tax accounts, and should receive the same treatment as that indicated in the legislation for dividends; and the same treatment should be given to loans between related parties. ${ }^{25}$ Nevertheless, the same article still provided that the net income of the branches and affiliates should be calculated based on separate accounting records.

However, not all rulings in this period were based on the economic reality principle. In 1969, the TFN ruled in favour of Le Carbone Lorraine S.A., in a case relating to the tax classification of amounts paid to the main shareholder as royalties. Again in 1972, in the case of Productos Químicos CIBA concerning royalty and interest payments made to related parties, the TFN ruled against the tax authority in relation to royalty payments, observing that it could not be concluded that the existence of a relationship invalidates license contracts for the use of brands and patents. ${ }^{26}$

\subsubsection{The pricing of imported and exported goods during this period}

In 1973, a modification was made to the export-import clause ${ }^{27}$ to expand the scope of the application of the arm length's principle in cases in which no wholesale prices were

See Parke Davis, Mellor Goodwin, Rheinstahl-Hanomag Cura, Compañía Swift de La Plata and Ford Motor Argentina cases in Appendix 1.

The reform of 1973 changed the name from 'Impuesto a los Reditos' to 'Impuesto a las Ganancias' (LIG). A description of these rulings and their implications, and an analysis of the regulatory changes which resulted, can be found in Martínez de Sucre and Corti 1976, Corti 1985, and Corti 2012.

These laws formed part of a package of 20 laws proposed to Congress during the 1973-1974 government of President Peron, aiming to achieve long-term sustainability for Economy Minister José Ber Gelbard's plan. Article 14 of Law 20.628.

Law 20.557 on foreign capital investment also stated in its Article 18 that foreign-owned companies making use of government benefit programmes would not be able to repatriate profits (dividends) for the duration of the benefits or obligations derived from such arrangements.

It should be clarified that in Argentina, rulings of the CSJN are meant to be used for the interpretation of the law, but they are not law. Also, the CSJN at different moments in time, with different members, can have a different understanding and rule differently.

Law 20.628 of December 1973 modified the export and import clause in the following way. Paragraphs 2 and 3 of Article 8 now read, in relation to the export of goods: '... if the price has not been fixed, or the price agreed was lower than the wholesale price at destination, it will be considered, except if otherwise proved, that there 
available to both import and export cases (since 1946, the Income Tax Law had only allowed for such mechanisms to be used for import cases).

The economic reality principle was not applied to export and import agreements (except when such transactions included other concepts, such as hidden interest payments). ${ }^{28}$ The ruling in which the economic reality principle had been applied to transactions of goods between related parties ${ }^{29}$ referred to transactions with related parties located in Argentina, and not abroad, for which the import-export clause would have been applicable. Indeed, no court thought it appropriate to consider exports or imports as mere transfers of merchandise between countries for which only the sale price to third parties at destination should be considered for taxation purposes.

\subsection{The shift to the independent entity principle (under the dictatorship) (1976-1983) and the restoration of democracy (1983-1998)}

The civilian-military coup of 24 March 1976 was supported and encouraged by local and foreign multinational entities (MNEs). ${ }^{30}$ Changes to the legislation affecting MNEs' investment interests in Argentina were among the first to be made, thus, since the economic reality principle was argued by MNEs to be too hostile to foreign investment, ${ }^{31}$ it was modified at a very early stage in the dictatorship. So, in August 1976, a new foreign investment law was passed validating contracts between related entities provided that they conformed to normal market practices between independent parties. ${ }^{32}$ The same modifications were soon after introduced to Article 14 of the LIG, ${ }^{33}$ and to the law on technology transfers. ${ }^{34}$

However, the legislative changes did not make any provision for how the tax authority should check that such practices between related parties were in effect carried out as if they had been between independent parties; and probably due to this reason, few cases were discussed in court, and they obtained contradictory rulings from the CSJN. ${ }^{35}$

All of these reforms affected intragroup payments relating to services, royalties and financial transactions, but not exports and imports of goods, which were still governed by Article 8 of the LIG.

exists an economic linkage between the exporter in the country and the importer abroad, so that such wholesale price at destination should be used in determining the value of the exported goods...' and, in relation to the import of goods: '...if the sales price to the buyer in the country is higher than the wholesale price at the place of origin plus - as appropriate - transport and insurance costs to the Argentine Republic, it will be considered, except when otherwise proved, that there exists an economic linkage between the importer in the country and the exporter abroad, so that the difference should be treated as a net profit of Argentine source for the latter.' This clause will from now on be referred to as Article 8 of the LIG.

See Rheinstahl Hanomag Cura S.A. in Appendix 1.

See Mellor Goodwin in Appendix 1.

The role of MNEs in the dictatorship is currently being discussed in court, because the involvement of MNEs was not only related to mere support of economic and political decisions taken by the coup, but also in relation to the disappearance of activists and union representatives working at such MNEs. Partly because of this, it is referred to in Argentina as a 'civilian-military coup'. It should also be recalled that this military coup was part of the Condor Plan implemented under the United States' National Security Doctrine aiming, among other things, at eradicating communist guerrillas in Latin America.

See Baistrocchi 2012 for a presentation of such arguments.

Article 20 of Law 21.382 of 13 August 1976.

On 17 December 1976, Article 14 of the Income Tax Law (LIG) was amended through Law 21.481 in the following way: 'The legal acts carried out between a local company with foreign capital and any physical or juridical person resident abroad that directly or indirectly controls it will be considered, to all effects as if carried out between independent parties when such activities and conditions conform to the normal practices of the market between independent entities...'

$34 \quad$ In 1977 a new Law, 21.617, on technology transfers legitimised contracts between economically related companies.

35 See cases Petroquímica Argentina S.A. and Kellogg Co. Arg. S.A.C.I.y.F. in Appendix 1. 
Following the return to democratic government on December 101983 , in 1984, more than 400 tax specialists formulated a proposal to the national government for comprehensive tax reform. This included a proposal to reaffirm the economic reality principle and the principle of contribution and benefit in the determination of the taxable base of entities belonging to an economic group or subject to one (Corti 2012). However, this proposal did not succeed because of a lack of political support and the tax reform was not carried out.

On February 26 1985, the CSJN ruled in the Kellogg case explicitly recognising the Parke Davis doctrine, reaffirming the economic reality principle, and applying it to payments between related companies within the country relating to royalty, loans and technical services, as well as sales. ${ }^{36}$ Nevertheless, the Kellogg case did not signal a return to the economic reality principle.

In 1992, the worldwide income principle was incorporated into the LIG. ${ }^{37}$ This applied to all residents in Argentina, including companies and their foreign subsidiaries. ${ }^{38}$ It provided that residents should calculate their taxable base on the total profits gained in the country and abroad, while they could deduct from their local income tax liability the actual payments made for similar taxes abroad.

\subsubsection{The pricing of imported and exported goods during this period}

In 1983, the CSJN ruled in favour of the taxpayer, in Eduardo Loussinian. The Tax Administration Department had challenged what it considered to be schemes to overinvoice imports, noting that a difference between the price paid and the current wholesale price in the place of origin supposed the existence of an economic linkage between the foreign company and the local importer; and that therefore this difference in prices constituted a net Argentine-source profit for the exporter, according to Article 8 of the LIG. Nevertheless, the CSJN took the view that it was not possible to verify whether there was an economic linkage (ownership relationship) between the foreign entities and Eduardo Loussinian S.A.C.I.F.I.A., and therefore the profit could not be said to be of Argentine source.

This case questioned the validity of the rule that had been in place since 1946, treating a difference between a wholesale price at origin and the importers price as implying an economic linkage between the parties.

\subsection{The introduction of the OECD Transfer Pricing Guidelines (1998-today) and the refinement of the 1976 approach}

Many changes were introduced into local legislation from 1998 onwards in relation to the treatment to be given to transactions between related parties, most of them aimed at making local rules consistent with the OECD approach (Baistrocchi 2012).

The five transfer pricing methods specified in the 1995 OECD Guidelines (OECD 1995) (comparable uncontrolled price (CUP), resale price minus, cost plus, profit split, and the transactional net margin method (TNMM)) were introduced in Article 15 of the LIG

\footnotetext{
For an in-depth analysis of this case and its relation to the application of the economic reality principle between 1972 and the Kellogg case, see Corti 1985.

Law 24.073 of April 1992 modified Article 1 of the LIG (text organised in 1986) so that all residents would be taxed on their total profits obtained in the country or abroad, allowing as tax deductions the taxes effectively paid on analogous taxes on their activities abroad. Non-residents should be taxed solely on their profits from Argentine sources.

It was not until the modifications to the LIG introduced by Laws 25.063, in 1998, and 25.239, in 1999, that the treatment to be given to foreign subsidiaries was clarified. For a brief discussion on the treatment given between 1992 and 1998 to profits of foreign source, see Gilardo 2007.
} 
in $1998^{39}$ for the determination of profit of Argentine source in transactions with related parties ${ }^{40,41}$ located abroad, or with entities located in countries of low or zero taxation. ${ }^{42}$ However, the law did not make any explicit mention of the OECD Guidelines. Argentina of course was not and is not a member of the OECD.

These transfer pricing methods became applicable to transactions ranging from the transfers of tangible (except when Article 8 is to be applied) and intangible property, services, financial transactions, and licensing of intangible property.

Transfer pricing documentation requirements were introduced in $2000^{43}$ and the requirement to file such documentation in $2001^{44}$ (see Appendix 2).

Also in line with the OECD Guidelines were the clarifications on what would be considered comparable transactions in each different type of transaction (financial, intangibles, services, etc.), and the comparability adjustments that could be used to reduce the differences in comparability. ${ }^{45}$

The interquartile range ${ }^{46}$ was introduced in $2001^{47}$ as the statistical technique to be used for transfer pricing purposes, again following the recommendations of the OECD Transfer Pricing Guidelines.

Thin capitalisation rules ${ }^{48}$ were first introduced in $1998^{49}$ establishing a ceiling for the deduction of interest of 2.5 times the net capital. These rules were modified in $2003^{50}$ to deny the deduction from taxable income of debt interest if the corresponding loan

These transfer pricing methods were incorporated into Article 15 of the LIG by Law 25.063 on 7 December 1998, taking effect from 31 December 1998. Article 15 had originally been introduced in 1947 and had not been subject to significant changes until 1998.

The economic linkage between two parties was very broadly defined by the same law in an article added to the LIG to follow Article 15 by Law 25.063. AFIP's General Resolution 1122/2001 defined more clearly how economic linkage should be understood, including, in addition to cases where a party owns more than 50 per cent of the capital of the other, cases where: two or more parties have directors, high level employees or managers in common; a party enjoys exclusivity as an agent, distributor or dealer for the purchase and sale of goods, services and rights of the other; a party provides the other with technological property or technical knowledge which forms the basis of the activities on which the latter conducts its business; and various other cases which overall prove the existence of economic collusion between two or more parties. Transfer pricing methods and regulations apply to transactions carried out with related parties located abroad which are corporations, branches, other types of companies, associations or partnership, trusts or similar entities; transactions between Argentine taxpayers and their permanent establishments abroad; transactions between the permanent establishments of Argentine taxpayers abroad and their related parties also located abroad (Articles 129 and 130 of the LIG) (PwC 2012). The list of the jurisdictions that would be considered of low or zero taxation was introduced in Decree $1037 / 2000$ which modified the Regulation of the LIG, as consolidated in 1997 and as amended, approved by Decree 1344/98.

43 Decree 1037/2000.

44 AFIP's General Resolutions 1122/01, 1007/01, 1296/02, 1339/02, 1590/03, 1508/03, 1517/03, 1524/03, $1530 / 03,1670 / 04,1918 / 05$, and more recently $3285 / 12$ regulate such documentary requirements. Decree 1037/2000 modified the implementing regulations of the LIG, as had been organised in 1997, and its modifications, approved by Decree 1344/98. Decree 1037/2000 indicates that comparable transactions are those with which there are no differences affecting the price, profit margin or amount of the payment. The interquartile range is used in relation to the application of the arm's length principle in order to select a range of prices or results from the comparable companies with which to compare the price or result of the transaction or entity under analysis. The interquartile range is a statistical ordering including the 50 per cent of the results in the middle of the scale of results.

$47 \quad$ AFIP's General Resolution 1122/2001.

$48 \quad$ Companies can finance themselves through using or by issuing debt or equity. When a company has a relatively high level of financing through debt compared to equity, it is said to be thinly capitalised, or highly leveraged or highly geared. A high level of debt will imply a high level of interest to be paid, thus reducing the taxable profit.

$49 \quad$ Law 25.063 of 7 December 1998

$50 \quad$ Article 4 of Law 27.784 substituted Article 81 of the LIG 
with controlling parties located abroad exceeds twice the net capital. The excess nondeductible interest should be treated as dividends. ${ }^{51}$

In 2013, the list of low and zero tax jurisdictions for the purposes of tax transparency 52 was replaced by a positive listing of cooperative jurisdictions. ${ }^{53,54}$ Decree 589/2013 introducing these changes mentions in its preamble Argentina's active membership of the G20 as well as issues relating to fiscal transparency and the need to develop policies against tax havens and promote the exchange of information; as well as Argentina joining the OECD Convention on Mutual Administrative Assistance in Fiscal Matters in November 2011. The new approach under the 2013 Decree defined a positive list of cooperative jurisdictions on the basis of TIEAs (Tax Information Exchange Agreements) or DTTs signed or under negotiation, retaining the option for the AFIP to remove such a jurisdiction from the list if the lack of such information exchange has been verified. The decree instructed AFIP to draw up such a list of cooperative jurisdictions and publish it on its website by January $2014 .{ }^{55}$

\subsubsection{Transfer pricing litigation in this period}

After the regulatory changes introduced from 1998 onwards, transfer pricing disputes multiplied, and several cases obtained rulings from the CSJN. Some examples will be presented here, and a complete list can be found in Appendix 1.

In the cases of both Bagó and of Nobleza Piccardo, the taxpayer argued that the lower prices charged when exporting to foreign related parties were justified by the fact that the local entity only performed 'contract manufacturer' activities with regard to its export transactions. The tax court rejected the Tax Administration's arguments proposing the application of other methods and comparables, considering either that the tax authority had failed to meet the burden of proof relevant for a transfer pricing dispute (in Bagó) or that its arguments were invalid (in Nobleza Piccardo).

In Daimler Chrysler Argentina S.A., exports between Mercedes Benz Argentina and Mercedes Benz Brazil were at a lower price than the wholesale price in Argentina. The TFN applied 'to all the exported units the difference in value between the price of the car in the domestic market and the export price of the same car' (D'Agostino 2010). The TFN's ruling cited the cases of Parke Davis (1973) and Kellogg (1985), among others, referring to the economic reality principle and the lack of independence of the affiliated company in relation to the contracted operations with the foreign related party. The parties appealed to the CCAF (part of the ruling had been against the tax authority), which overruled the TFN, quashing the AFIP's decision which had initially been appealed by the company. Both parties appealed to the CSJN, and the latter confirmed the CCAF's decision in a ruling on 1 April 2014.

After the modification of the LIG (Law 26.893, approved in September 2013) relating to the taxing of dividends and the utility principle, and Article 81 of the LIG, and after Decree 589 of May 2013 was passed, it was provided that interest payments to a lender resident in a non-cooperative jurisdiction can be deducted, but will be subject to a 35 per cent withholding tax; for transactions with an entity in a cooperative jurisdiction, the thin capitalisation debt limit of twice the net capital applies; deductible interest payments will be taxed at 15.05 per cent, while the excess payments denied deduction will be taxed as dividends at a 10 per cent tax rate. As has been mentioned in a previous footnote, Decree 20137/2000 listed 88 domains, jurisdictions, territories, associated states or special tax regimes that were to be considered 'countries of low or zero tax'. Decree 589 of May 2013 replaced the list in Decree 1037/2000. AFIP General Resolution 3576 of 27 December 2013 specifies that cooperative jurisdictions include those with which Argentina has signed an agreement; those with which an agreement has been signed but the effectiveness of the exchange of information has not yet been evaluated; and those with which negotiations for the signature of an agreement have begun. See www.afip.gov.ar/noticias/20160405jurisdiccionesCooperantes.asp (accessed 6 December 2016). 
In the case of Aventis Pharma, the AFIP had challenged one of the companies chosen as comparables when applying the TNMM, due to its recurring losses. The TFN ruled in 2010 in favour of the taxpayer, stating that the tax authority had not presented sufficient arguments to overrule the transfer pricing report presented by Aventis Pharma. The case also referred to two other issues, one being whether the results of the comparables should be adjusted to take account of the discounts given by Aventis Pharma for sales to a government agency; and the other the treatment as income of payments for research and development. Both these arguments were also lost by the tax authority.

In the case of Boehringer Ingelheim S.A., the tax authority objected to: 1) the comparable companies chosen; 2) averaging the results of several years both of the tested party and of the comparable companies for the purpose of analysing the results of the company for the fiscal year 1999; 3) the functional analysis performed in which the activities of the company were segmented into different activities and functions; 4) the choice of the financial indicators; and 5) the fact that no country risk adjustment was made. The TFN found in 2012 both that the tax authority had not presented sufficient arguments to support its position, and that its position was wrong.

In Volkswagen Argentina S.A., in fiscal year 1999 the company had made idle capacity, dismissal compensation, and bad debt adjustments on the results obtained by the independent comparables chosen, to which AFIP objected. The tax court decided in favour of Volkswagen Argentina S.A., arguing that the taxpayer's transfer pricing study reversed the burden of proof onto the tax authority. Comparability adjustments based on the idle capacity of the tested party were also questioned by AFIP in the Toyota Argentina S.A. case, again resulting in a ruling in favour of the taxpayer from the CSJN in 2014.

\subsubsection{Introduction of the Sixth Method for the pricing of commodity exports}

Probably as a consequence of Eduardo Loussinian S.A.C.I.F.I.A, Article 8 of the LIG was modified in 1998 in order to make it applicable even when the economic linkage between the parties cannot be verified. ${ }^{56}$

Article 8 was amended again in $2003,{ }^{57}$ to provide that in cases of transactions with related parties, as well as with parties located in low or zero tax jurisdictions, Article 15 of the LIG should be applied. ${ }^{58}$ Also, in cases of import or exports for which an international price can be established in a transparent market, such a price should be applied to determine the profit of Argentine source.

Finally, the same law amending Article 8 incorporated a sixth paragraph after the five OECD methods specified in Article 15 of the LIG, applying to cases of commodity exports where international intermediaries are involved, under which prices should be based on 'the trading value of the goods in a transparent market on the date on which

Law 25.063 of 7 December 1998 modified Article 8 of the LIG. Also, Decree 485 of 7 May 1999 introduced equivalent changes in Article 11 of the Regulatory Decree 1344/1998. Before these changes, the regulations under the LIG, approved by Decree 1344 of 19 November 1998, indicated in Article 11 of Decree 1344/1998 that once the existence of an economic relation had been verified (Article 8 of the LIG), the AFIP could also determine the value attributed to the products involved in the transaction taking the wholesale price in the seller's market in case of an export, or the wholesale price in the buyer's market in case of an import. In any case, when the real prices of export or import were respectively higher or lower, such prices should be considered.

$57 \quad$ Modifications introduced by Law 25.784 of 2003.

58 Decree 916/2004 clarified the application of Article 8 of the LIG and extended its application also to transactions between unrelated parties if the importer or exporter abroad is a physical or juridical person constituted or resident in a low or zero tax jurisdiction. In such cases Article 15 of the LIG must be applied for the pricing of such transactions. 
the goods are shipped'. The application of this Sixth Method is specifically required only when the foreign intermediary cannot demonstrate economic substance. In this sixth paragraph, economic substance is defined as a) having real presence in the territory of residence, and assets, functions and risks of a similar weight to the volumes of transactions negotiated; b) its main activity must not constitute the obtaining of passive income, nor the intermediation of sales of goods from and to Argentina or with other members of the economic group; and c) its foreign trade operations with other members of the same economic group do not exceed 30 per cent of the total annual turnover of the entity. These conditions are cumulative, not alternative.

From 2003 onwards, AFIP attempted to apply the Sixth Method in several cases that reached different court levels. However it did not always succeed in this application because all such cases related to fiscal years prior to the method's introduction into Article 15 (2003), and so the AFIP's attempts faced the problem that legislative changes can only be applied prospectively.

In Nidera S.A., the company exported commodities (cereals and oils) through intermediaries resident in tax havens, and argued that its export prices should be based on the export prices at the date of the agreement. The case discussed whether the Sixth Method, Article 8 of the LIG, or the CUP Method should have been applied. The tax authority finally suggested the application of the CUP Method (Article 15 of the LIG) using the prices published by the Secretary of Agriculture in Argentina at the shipping date, based on the analysis of the behaviour of other comparable companies (Alfred C. Toepfer and La Plata Cereal S.A.). The TFN ruled in favour of the tax authority and the CCAF upheld the decision of the TFN. The CCAF also held, in 2013, that the burden of proof of showing what independent parties had done fell on the taxpayer.

However, in the case of Oleaginosa Moreno S.A.C.I.F.I.A.(relating to the fiscal year 2000), when the AFIP suggested that the price at the shipping date be applied to the export price of commodities to a related party located in Switzerland, the TFN partially confirmed the AFIP's position, observing that the legislation in place was consistent with the methodology chosen by the AFIP, but the CCAF later ruled in favour of Oleaginosa Moreno, based on the fact that AFIP was using a methodology for the calculation of the prices that was not in line with the legislation in place during the fiscal year under question. The AFIP's further appeal to the CSJN was also rejected in 2014.

Also, in the Toepfer case, the tax authority argued that for the Sixth Method the exchange-quoted price at the shipping date could be used, but the tax court ruled that it could only be applied prospectively since the case pre-dated the introduction of the Sixth Method. On appeal, the CCAF accepted the adjustments proposed by the tax authority, but only for those transactions for which the taxpayer could not prove the transaction date. The CSJN finally ruled on 25 March 2015 in favour of the taxpayer, based on the grounds that the Sixth Method could only be applied prospectively.

\section{Problems with the arm's length principle}

\subsection{Difficulties with the application of the arm's length principle}

Since the incorporation of the arm's length standard into Argentine legislation (1976) there have been a series of contradictory rulings (see Appendix 1). This has resulted in a system which is not clear either for the taxpayers or for the tax authority. 
The contradictory and confusing character of Argentina's transfer pricing jurisprudence seems to be a consequence of the interpretation given to the continuing existence of the economic substance doctrine and its interpretation in the Parke Davis case, and the later introduction of the arm's length principle in Argentine legislation. Thus, while Article 15 of the LIG is based on the arm's length principle, the first two articles of the Federal Act on Tax Procedures, as amended in 1998, refer to the economic reality principle. ${ }^{59}$

One of the recurring problems in transfer pricing litigation is the interpretation of the economic linkage between two parties. ${ }^{60}$ Due to the difficulties that on occasions are found when determining whether a local entity is controlled by a foreign entity, Argentine legislation partly dealt with it until 1998 in export and import cases - as discussed above - by applying the principle that a transaction was deemed to be based on an economic linkage if its export price was lower than the wholesale price at destination; or its import price was higher than the wholesale price at origin (taking into consideration transport and insurance costs).

After the turn in legislation towards the arm's length principle (in 1976), and before the OECD transfer pricing methods were introduced in Argentine legislation, Article 14 of the LIG indicated that transactions between related parties would be treated 'as if carried out between independent parties when such activities and conditions conform to the normal practices of the market between independent entities' and Article 15 indicated that '...the calculation of income sourced in Argentina shall be made on the basis of the percentage of profit obtained by independent enterprises engaged in identical or similar activities...'. However, tax auditors argued that there was no clear definition of how such comparison with independent parties' profits should be made. ${ }^{61}$

After the transfer pricing methods were introduced in local legislation, transfer pricing disputes focused mainly on comparability issues: whether the comparables chosen were appropriate; if geographical and other economic circumstances had been considered; and whether the comparability adjustments been sufficiently justified.

As has been analysed in Section 2, since 2003, for cases of commodities operations through foreign intermediaries without economic substance, the Sixth Method has been applied in Argentina, which consists of comparing the price agreed between related parties with the 'trading value of the goods in a transparent market at the date on which the goods are shipped'. ${ }^{2}$

In all other cases, Argentine legislation provides a number of methods which can be used to establish the prices between related parties as if they were between independent parties. These methods are also recommended in the OECD Transfer

It is worth mentioning a recent case (2013) which, although not related to transfer pricing, indicates a possible revival of the economic reality concept by the TFN, the case involving Molinos Río de La Plata and the AFIP. The company had established a holding company in Chile and taken advantage of so-called investment platform companies which do not pay taxes in Chile on income received or earned from foreign sources. Because of Argentina's DTT with Chile, Molinos Rio de la Plata S.A. considered that their income should not be taxed in Argentina either. AFIP considered that the dividends received by the Argentine controlling company from the entities located in Peru and Uruguay that had been routed through a Chilean holding were liable for income tax, and that there had been an abuse of the DTT with Chile, based on the 'economic reality' principle act to be interpreted based on the effective and economic intention of the taxpayer. The TFN ruled in favour of the tax authority. 
Pricing Guidelines (2010) and the United Nations Practical Manual on Transfer Pricing for Developing Countries (2013).

Except when the profit split method is used, the application of the arm's length principle requires a search for 'comparables', i.e. transactions between or profits made by independent companies.

As pointed out by Felitte (2003), in Argentina, transactions by the taxpayer with independent entities (internal comparables) have usually not been seen as valid comparables. This is because taxpayers generally argue - and the tax authorities and courts have difficulties refuting - that transactions with related entities involve fewer functions, assets and risks than those in transactions with independent parties; ${ }^{63}$ there are also geographical market differences, since related parties are abroad while independent parties tend to be within the domestic market.

Once internal comparables are rejected, comparable prices or profits must be found externally. Such comparables may be found for commodities traded in international markets, or specific transactions such as loans, royalty payments and sometimes, management services. ${ }^{64}$ In other cases, independent party transactions are usually not regarded as comparable because transactions between related parties are usually found to involve associated intangibles, the effects of which on prices are difficult to unbundle.

The AFIP acknowledges that it has problems in relation to the lack of comparables and lack of information on costs incurred by the foreign related party. During interviews, AFIP officials mentioned a case in which the analysis related to the importation of iron ore. The best method chosen by the taxpayer was cost plus, but the AFIP encountered problems when trying to access information on the calculation of the cost.

Consequently, the analysis of intragroup transactions generally leads to the comparison of the profits earned by the entity in its related party transactions with those of comparable independent entities. The financial results of the entity are for this purpose segmented between the different related party transactions, i.e. the results of export transactions with related parties are separated from the results of import transactions with related parties, and from the results of manufacturing and distribution activities performed with independent parties.

This is the reason why the TNMM is found to be the method employed most often (CIAT 2013), since traditional transaction methods (CUP, resale price minus and cost plus) are discarded for the reasons described above. As regards the profit split method, which is the other transactional profit method provided for in the legislation (and in the OECD transfer pricing guidelines), the AFIP considers it to be difficult to apply due to the problems of obtaining information about a group's costs, profits, etc.

However, searching for financial results for external comparables also involves a number of difficulties, the first of these being the lack of available financial information about companies in developing countries which are not foreign-owned. ${ }^{65}$ Particularly in

See the cases Oleaginosa Moreno, Laboratorios Bagó, and Nobleza Piccardo, described and listed in Appendix 1.

$64 \quad$ Tax advisors use LexisNexis Contract Database and RoyaltyStat to search for comparable agreements for the CUP analysis of royalties, technology transfer and, on occasions, management services transactions. In the case of loans, they use local and foreign public information on interest rates generally published by the country's Central Bank. There are no cases in which the validity of such comparables has been challenged by the AFIP.

65 According to data from the National Survey of Large Enterprises in Argentina (Encuesta Nacional de Grandes Empresas, ENGE) published by the Report on Large Enterprises in Argentina produced by the National
} 
the case of Argentina, although Argentine companies are required to make their annual accounts publicly available by filing a copy with the General Justice Inspectorate (IGJ), there are bureaucratic impediments to accessing this information. ${ }^{66}$ Even if access was possible, there are usually very few independent companies with activities comparable to those performed by the tested party.

Therefore, although local comparisons are sometimes used, ${ }^{67}$ in most cases a search for comparables is conducted on international databases, which contain accounting data from companies listed on the stock exchanges in various parts of the world. The AFIP uses the Osiris database (published by Bureau van Dijk), because it contains a higher number of small firms from developing countries. While tax advisors in Argentina do use Osiris, they also use Compustat Global (published by Standard \& Poors), containing a greater coverage of large companies in more developed countries with a wider range of accounting data items than any other database. ${ }^{68}$

Given the limitations of comparing the results from subsidiaries of transnational groups with results from independent companies, local regulations - following the OECD Guidelines - suggest a number of adjustments to reduce the differences arising from using different accounting criteria, the specific nature of the markets and the distinct economic conditions in different geographical markets. Regulations provide that several factors should be taken into account, including payment dates, amounts involved, advertising and promotion expenditures, intermediation costs, insurance and freight, physical nature of the content, differences between the dates of the transactions, and currency. ${ }^{69}$ The use of such comparability adjustments can sometimes be excessive; however, the AFIP has had little success when attempting to challenge them. ${ }^{70}$

Another issue is the burden of proof. In principle the burden of proof lies on the taxpayer, since the legislation requires the presentation of transfer pricing documentation ${ }^{71}$ to justify that the prices are at arm's length in case of transactions with related parties or with parties located in non-cooperative jurisdictions. However, if the AFIP proposes an adjustment to the tax base, e.g. based on challenging the comparables chosen or the comparability adjustments made, and the taxpayer appeals to the National Tax Court, the court has generally taken the view that the burden of proof for the justification of such adjustment, e.g. presenting other comparables or evidence for challenging the comparability adjustments, lies with the AFIP. ${ }^{72}$

Also, the issue of the validity of intragroup contracts has not been made clear in court cases. Some court rulings have considered the existence of a contract as a requirement for validating an intragroup transaction; ${ }^{73}$ and other rulings have found that there is no need for a contract in transactions within an economic group, and in an

Institute of Statistics and Census (Instituto Nacional de Estadística y Censos, INDEC) in January 2014, of the largest 500 surveyed, 321 (64.2 per cent) had foreign participation in 2012, defined as ownership of 10 per cent or more of the capital.

Access is by application for each individual company. Although searches can be made online, applications are required to be made in person and on paper; the accounts are provided on paper; and a legitimate interest in the use of the data needs to be proved by means of a letter from the institution requesting the data.

Profit and loss accounts from independent local entities are sometimes used in the insurance sector, for which balance sheets are available and presented in the same format, so they can be easily processed.

For an analysis of accounting databases see Dai 2012.

Decree 1037/ 2000 (which modified the Regulation of the LIG revised in 1997 and approved by Decree 1344/1998).

See Boehringer Ingelheim S.A. and Toyota Argentina cases described in Appendix 1.

Appendix 2 provides a brief description of local transfer pricing documentation requirements.

See Laboratorios Bagó case described in Appendix 1.

See Litoral Gas case described in Appendix 1. 
inverse application of the economic reality principle, have found that an internal memo is as valid as an intragroup contract. ${ }^{74}$

The AFIP has also encountered problems when attempting to verify the financial data used as a basis for the calculation of royalty, technology transfer and management services or central services charges. In relation to loans, the AFIP has questioned their nature (whether they should be considered a capital transfer), and the interest rates. However, MNEs normally justify interest rates using publicly known rates, so such rates are normally found to be at market level.

Finally, the AFIP has not challenged some of the main devices used for BEPS, notably restructurings, contract manufacturing, contract distribution or contract research and development schemes. ${ }^{75,76}$ This seems to be for two main reasons. Firstly, existing regulations do not provide for any other tools besides those of analysing functions performed, risks assumed and assets owned by the taxpayer in the intragroup transactions. Secondly, it is very difficult to imagine the complete picture of an MNE's global value chain when observing only the activities performed by the local affiliate.

Today the AFIP does not question the appropriateness of the OECD proposed methodology or the arm's length principle, and the OECD Guidelines have been used as soft law by tax courts since $1998 .{ }^{77}$

As observed in the very complete listing of transfer pricing cases provided in Appendix 1 , most of the court decisions have been in favour of the taxpayer. ${ }^{78}$ When an unfavourable result is obtained in the TFN, AFIP lawyers analyse the possibility of obtaining a favourable result in a higher court before appealing. Therefore, not all of these cases have been pursued. This explains the comparatively small number of cases which have obtained a ruling from the CSJN.

\subsection{Solutions implemented by the AFIP to improve the effectiveness of transfer pricing audits}

The AFIP has implemented the following solutions in order to better tackle transfer pricing manipulation.

- Liaison with other Government departments (Customs, Central Bank, etc.) to obtain information for research audits.

- In relation to the lack of comparables:

- AFIP has been using the Osiris database since 2011 to verify the comparables chosen and the validity of the comparability analysis presented by taxpayers on their transfer pricing reports. Before that, the

\footnotetext{
${ }^{74}$ See Ericsson case described in Appendix 1.

Contract manufacturing, contract distribution and contract $\mathrm{R}$ and $\mathrm{D}$ may not be per se a source of base erosion and profit shifting. However, given that the separate entity criteria and the arm's length principle allow companies to contractually locate assets, risks and functions in any jurisdiction, and that within an economic group, two parties are not situated in equally independent conditions when negotiating, then such schemes can turn into sources for BEPS.

76 For a description and examples of such schemes, see OECD 2010: 260.

Customary international law has never been used by the tax authority to fill in gaps in the relevant methods for solving transfer pricing disputes between 1932 and 2011. There have been at least eight large transfer pricing cases litigated in Argentina since the country began transplanting the OECD Guidelines into domestic law in 1998. In most disputes, the taxpayer won on procedural grounds based (either explicitly or implicitly) on the OECD Guidelines. Thus, the tax court has been using the OECD Guidelines as soft law to fill in gaps in domestic law since 1998 (Baistrocchi 2012).

78 According to CIAT's 2013 report on transfer pricing, the AFIP stated that between 2007 and 2012, five rulings favoured the taxpayer and five favoured the AFIP, one of these being a ruling which only partially favoured the AFIP
} 
AFIP had to trust the information on comparable companies presented by the taxpayers, or had to go through several difficult processes in order to find more information.

- Improved use of the customs database.

- Improvement in information requests to multinational companies.

- Improving automatic information exchange; for example, through the INDIRA system and through information exchange agreements.

- Information available through INDIRA consists of customs information, and is used for international tax research purposes, mainly to analyse triangulations, and the final price and amounts at destination of the goods exported. This information constitutes the starting point for research that may later lead to tax audits.

- Information exchange agreements are used in order to:

- obtain information on the economic substance of trade intermediaries (for the purpose of applying the Sixth Method for pricing commodity exports);

- get information on the import price at destination of goods exported from Argentina;

- clarify the economic relationship with the local taxpayer of the foreign entity concerned (for example, functional relationship, shareholders, clients, etc.).

- The AFIP is also working on improving the expertise of tax inspectors in transfer pricing audits.

There are no Advance Pricing Agreements (APAs) ${ }^{79}$ in Argentina. However, in 2015 the Ministry of Economy was evaluating whether to provide for APAs in local legislation. There is the possibility of requesting binding consultations ${ }^{80}$ from the AFIP which, even if not the same as APAs, are a tool that companies use in order to obtain more certainty on whether their interpretation and application of the regulations in place will be sustained under an audit. However, this procedure has not been used in relation to transfer pricing.

\subsection{Measuring the effectiveness of transfer pricing audits}

There are some effectiveness measurements in relation to transfer pricing. For example, in relation to transfer pricing audits, a measurement of their success is the adjustments to the tax base that have been made, or the cases that have reached the tax court.

In this respect, the AFIP monitors, for example, the spontaneous adjustments ${ }^{81}$ made to the tax base by the taxpayers themselves in their transfer pricing declarations.

APAs are arrangements between taxpayers and tax authorities in which the taxpayer determines in advance, and for an amount of years provided by the regulations of the jurisdiction, the methodology to be used for the pricing of controlled transactions. Such arrangements involve a necessary negotiation between taxpayers and the tax authority.

80 The binding consultations regime in Argentina is governed by the AFIP's General Resolution 1948 of 2005 and consists of all technical-legal consultations made with the AFIP in relation to the determination of taxes and social security contributions. The results of such a binding consultation have to be considered in case of a tax audit.

81 Spontaneous adjustments occur when an entity has presented its tax declarations, but when later filing the transfer pricing report and forms observes that it cannot justify the value of the transactions under the current legislation, and thus makes 'spontaneous adjustments' to its taxable base. 
Table 4 Spontaneous adjustment to the tax base and income tax based on transfer pricing declarations ${ }^{82}$

\begin{tabular}{llll}
\hline Fiscal year & Number of taxpayers & $\begin{array}{l}\text { Adjustment to the tax } \\
\text { base (Argentine pesos) }\end{array}$ & $\begin{array}{l}\text { Tax value (35\%) in } \\
\text { Argentine pesos }\end{array}$ \\
\hline $\mathbf{2 0 0 3}$ & 89 & $426,329,471.41$ & $149,215,314.99$ \\
$\mathbf{2 0 0 4}$ & 99 & $307,409,386.73$ & $107,593,285.36$ \\
$\mathbf{2 0 0 5}$ & 82 & $181,910,923.85$ & $63,668,823.35$ \\
$\mathbf{2 0 0 6}$ & 101 & $437,591,962.09$ & $153,157,186.73$ \\
$\mathbf{2 0 0 7}$ & 117 & $158,601,859.22$ & $55,510,650.73$ \\
$\mathbf{2 0 0 8}$ & 96 & $319,947,221.35$ & $111,981,527.47$ \\
$\mathbf{2 0 0 9}$ & 94 & $288,576,275.77$ & $101,001,696.52$ \\
$\mathbf{2 0 1 0}$ & 83 & $35,563,452.93$ & $12,447,208.53$ \\
$\mathbf{2 0 1 1}$ & 78 & $42,240,509.30$ & $14,784,178.26$ \\
\hline
\end{tabular}

Source: Elaborated based on Echegaray, Michel and Barzola 2013: 109.

The AFIP considers the evolution of such spontaneous adjustments as a direct effect of the application of transfer pricing regulations.

However, the AFIP interprets the reduction of the spontaneous adjustments to the tax base over time (from 426 million Argentine Pesos in 2003 to 42 million in 2011, see Table 5) as a consequence of adjustments to the price of commodities (the application of the Sixth Method), as a consequence of taxpayers giving traders an alleged 'economic substance' in order to avoid the application of the Sixth Method for the valuation of commodities (Echegaray et al. 2013: 110).

Table 5 Spontaneous adjustment to the tax base and income tax, as a consequence of adjustments to the price of commodities

\begin{tabular}{llll}
\hline Fiscal Year & $\begin{array}{l}\text { Number of } \\
\text { taxpayers }\end{array}$ & $\begin{array}{l}\text { Adjustment to the tax base } \\
\text { (Argentine pesos) }\end{array}$ & $\begin{array}{l}\text { Tax value (35\%) in } \\
\text { Argentine pesos }\end{array}$ \\
\hline 2003 & 13 & $369,624,402.04$ & $129,368,540.71$ \\
2004 & 40 & $226,928,170.78$ & $79,424,859.77$ \\
2005 & 11 & $121,367,737.80$ & $42,478,708.23$ \\
2006 & 7 & $359,692,301.95$ & $125,892,305.68$ \\
2007 & 4 & $974,886.17$ & $341,210.16$ \\
2008 & 4 & $591,030.15$ & $206,860.55$ \\
2009 & 6 & $6,479,686.64$ & $2,267,890.32$ \\
\hline 2010 & 3 & $11,285,639.30$ & $3,949,973.76$ \\
2011 & 4 & $4,248,810.86$ & $1,487,083.80$ \\
\hline
\end{tabular}

Source: Elaborated based on Echegaray, Michel and Barzola 2013: 110.

It is also possible to make some analysis of the data collected in tax declarations relating to transfer pricing and the transfer pricing documentation ${ }^{83}$ presented by MNEs. From such information, the AFIP can analyse the conduct of the MNEs by economic sector, analyse what is reported in relation to transfer pricing, and analyse the conduct of MNEs in relation to specific transactions. Such information is confidential, and is used by the AFIP for research purposes in order to plan a strategy for tax audit, but also to evaluate the effectiveness of the transfer pricing regulations. authority. It only reflects the spontaneous adjustments made by the taxpayers in order to comply with transfer pricing regulations in place.

83 Appendix 2 provides a brief description of local transfer pricing documentation requirements. 
An example of the use of such information for measuring the effectiveness of transfer pricing regulations is seen in the following table, in which an analysis was made of the price differences between origin and destination of Argentine commodity exports by large concentrated export groups (mainly linked to the oil and oilseeds sector) when using different intermediaries.

Table 6 Various triangulation situations found by the AFIP since 2009

\begin{tabular}{llll}
\hline In Argentina & Intermediary & End client & Price difference \\
\hline Dutch Capital & Related company Asia & China - Europe - Brazil & $5 \%$ \\
US Capital & American branch & China, Spain, Malaysia, India & $5 \%$ \\
German Capital & Parent company Europe & China, Spain, Brazil, Chile & $5 \%-10 \%$ \\
Argentine & American branch & China - Spain & $5 \%-10 \%$ \\
US Capital & US parent company & China, Saudi Arabia, Syria & $5 \%$ \\
\hline
\end{tabular}

Source: Echegaray, Michel and Barzola 2013: 86.

\section{Coordination with foreign tax authorities}

Argentina has gone through different stages in the negotiation of DTTs, the last one beginning in $1992 .{ }^{84}$

From 1962, the DTT signed with Sweden was applicable, in which the mechanism adopted for eliminating double taxation gave the exclusive rights to tax to the country of origin of the income. In 1967, the treaty with Germany began to be applicable, which had been based on the OECD Model of 1963, since Argentina did not have a clear position on tax treaties at the time, as a dictatorship was in power. For this reason, in the democratic government of 1973, this 1967 treaty was denounced by the Argentine government as being too disadvantageous to the source country. A new treaty was signed in 1979 that, although improving source tax rights, did not change the basic methodology provided in the recently approved UN Model tax treaty ${ }^{85}$ to avoid double taxation, which had not been seen by developing countries as being very favourable to source countries (Figueroa 2005).

In 1976, new treaties were negotiated with several countries, including all Western European countries, the Soviet Union, Japan, the USA, Canada, Hungary, Romania, Yugoslavia, Bolivia, Brazil and Chile. The treaty with Bolivia and Chile was based on the Andean Pact model, which favoured source country taxation; and a treaty was negotiated with Brazil, which should be denounced by Argentina due to the fact that it does not allow for Argentina to tax profits earned from Brazil by its residents, while Brazil can tax Argentine source profits earned by Brazilian residents (Figueroa 2005).

No DTTs were negotiated between 1981 and 1992 because the democratic government which came into power in 1983 considered DTTs (in their UN/OECD Model versions) to be a fiscal sacrifice for the source country. However, the government elected in 1989 had another position and began a third negotiating stage in 1992. The negotiations from 1992 onwards followed the UN Model approved in 1979, but reduced source withholding taxes. A Most Favoured Nation Clause ('MFNC') was incorporated by which Argentina committed to not granting greater concessions to

For an in-depth analysis of such stages and the implications they had for Argentina, see Figueroa 2005. This UN Model tax treaty was based on the OECD Model, and although different to the latter, does not reflect substantial changes to the OECD Model, and will for this reason be hereinafter referred to as UN/OECD Model Tax Treaties. 
an OECD member country than the ones granted to the country with which the first treaty of this period had been agreed (Figueroa 2005).

DTT negotiations were stopped in 2002 (although some treaties for which negotiations had begun at an earlier date were subsequently ratified), because it was observed that the losses caused to Argentina were not compensated by significant inflows of investment (Figueroa 2005).

In 2009 Argentina denounced the DTT with Austria, because the exclusive taxation of interest payments at source meant that Argentine residents were not taxed in relation to bonds issued by the Austrian government. The treaty with Chile was also cancelled, for a similar reason in relation to government bonds, but also because it allowed the Chilean investment platforms or investment companies, which did not pay taxes in Chile, to be used to avoid paying taxes in both Chile and Argentina. Agreements with Switzerland and Spain were also denounced. The agreement with Spain was denounced because of the exclusive imposition of the country of residence's taxation in relation to the stocks of Argentine companies, and because of the existence in Spain of a similar regime as that of Chile, the ETVE. ${ }^{86}$ Because of the agreement with Switzerland, which was in an irregular situation in Argentina because it had never been ratified by Congress (a requirement for all treaties), Argentina could not apply the withholding tax to royalty payments nor taxes on capital to stocks owned by Swiss residents.

TIEAs signed by Argentina indicate that the AFIP is the competent authority, while the DTTs indicate that the Ministry of Economy is the competent authority. However, the Ministry of Economy has delegated its powers to the AFIP. And the AFIP's Director has designated four tax officials to act as competent authorities for both TIEAs and DTTs, among whom is the Sub General Director of Tax Auditing (OECD 2013).

In relation to information exchange, the AFIP liaises with foreign tax authorities at precourt (administrative) levels. However, most of the information exchange cooperation between Argentina and other jurisdictions does not occur in relation to transfer pricing cases. Despite this, the AFIP has commented that some bilateral exchange of information takes place to verify data on the related parties located abroad or the parties located in low or zero tax jurisdictions. The AFIP acknowledges having encountered problems with tax havens when requesting information, particularly since in many cases that information request has been notified to the taxpayer abroad.

Although there has been information exchange and cooperation with other tax authorities (e.g. Brazil) relating to specific transactions or companies, there is no regular procedure for joint investigations (PwC 2012).

The structure of the law for solving transfer pricing disputes has two core dimensions in Argentina: domestic and tax treaty laws. On the domestic law front, the structure is based on the standard litigation procedures provided for in the Federal Act on Tax Procedures. ${ }^{87}$ On the tax treaty law front, the structure is based on the Mutual Agreement Procedure (MAP).

The MAP provisions are based on Article 25 of the OECD Model Convention. MAPs have been included in the Argentine tax treaty network since 1966, when Argentina concluded its first tax treaty with Germany. The number of DTTs which include Article

The Entidad de Tenencia de Valores Extranjeros (ETVE), was a type of entity that had as an objective the holding and management of shares of non-resident entities and was subject to a special tax treatment that exempted shareholders of paying taxes to dividends from foreign entities.

Ley de Procedimiento Tributario, No. 11.683, which became effective in 1933. 
25 has substantially increased over time: from one in 1966 to 14 in 2010, and the AFIP is the competent authority in relation to DTTs (Baistrocchi 2012). Today, the number of DTTs including Article 25 is $17 . .^{8}$

However, the method for solving transfer pricing disputes has been litigation, rather than the MAP. There have been at least 12 major transfer pricing cases reaching the courts between 1932 and 2011, yet no MAPs have been agreed (Baistrocchi 2012). Taxpayers have made a few applications for MAPs in relation to transfer pricing, which were received by the designated competent authority, but have remained unsolved. ${ }^{89}$ This seems to be because the AFIP cannot respond to the requests since there is no specific internal procedure for doing so (Baistrocchi 2012).

There have been intentions to modify the local regulations in order to include a procedure for bilateral MAPs, and the AFIP has committed itself to such changes, but so far, these intentions have not been acted upon. This may now occur as a result of the commitments under BEPS Action 14 to improve the MAP.

\section{Regulatory changes relating to the G20/OECD BEPS Action Plan}

In November 2014 a unit was created (Decree 2103/2014) in the President's office to monitor foreign trade (Unidad de Seguimiento y Trazabilidad de las Operaciones de Comercio Exterior), by verifying the price and amount of exported and imported goods and services in addition to the incoming and outgoing capital flows (considering the manipulation of transfer pricing as one of the mechanisms used for capital flight). This Monitoring Unit was formed by representatives from the Ministry of Economy, the AFIP, the Central Bank of the Argentine Republic (BCRA), the stock exchange's national supervision commission (CNV), the national insurance supervision office, the Financial Information Unit (UIF), and the Attorney General's office on Economic Crimes and Money Laundering (PROCELAC). Although these officials met throughout 2015, the activities of this Monitoring Unit did not continue after the change of government in December 2015.

At the time of writing, ${ }^{90}$ there have not been any regulatory changes relating to the BEPS Action Plan, ${ }^{91}$ partly because the AFIP needs to evaluate whether the proposed solutions will favour developing countries' tax collection or not.

For example, there have been some discussions about the treatment given to the valuation of commodities. According to the AFIP, the local application of the Sixth Method for commodity valuation is not incompatible with the BEPS Action Plan. This is primarily because the BEPS Action Plan did not question Argentina's Sixth Method, but also because the BEPS Action Plan will generate modifications in the transfer pricing guidelines, ${ }^{92}$ which countries may decide how to use in order to design their own local

\footnotetext{
$88 \quad$ See www.afip.gov.ar/institucional/acuerdos.asp (accessed 7 December 2016).

$89 \quad$ According to data published by the OECD, two cases were received in 2008, and three in 2009; three are also mentioned for 2010, but it is not clear that these are new cases. (OECD Map Statistics, see www.oecd.org/ctp/dispute/map-statistics-2014.htm (accessed 7 December 2016). All cases remain unresolved (EY 2014).

March 2016.

Except for the creation of a Registry of Related Parties (AFIP General Resolution 3572/2013), that registers local taxpayers' related parties.

Transfer pricing guidelines have not been mentioned in any norms, but have been referred to in court cases such as Ericsson, Aventis Pharma, Cisco and Alfred Toepfer (see Appendix 1).
} 
regulations. In the view of the AFIP, the report resulting from the BEPS Action Plan on the Sixth Method does not specify how the valuation of commodities must be done in each country. ${ }^{93}$

The AFIP was initially contacted by the OECD in relation to the BEPS Action Plan, in order to make a presentation of the local application of the Sixth Method for commodity valuation, and the AFIP effectively did that presentation. In addition, the AFIP has supported the G20/OECD's BEPS Action Plan from September 2013, with comments relating to taking into account the different realities of developing countries, through an interdisciplinary group involving the AFIP and the Ministry of Economy. It actively participated in all of the G20/OECD's BEPS Action Plan discussions from the beginning, and in particular, in the discussion of 'BEPS Action 10: Transfer pricing aspects of cross-border commodity transactions'. In relation to this discussion, the AFIP did not participate in its writing, but accepted it, understanding that the differences with Argentina's practices did not affect the local application of the Sixth Method. In this respect, the understanding of the AFIP was that the outcome of this action point should be understood as recommendations to be applied by each country under their own criteria and legislation. ${ }^{94}$

Argentina understood from the beginning of the discussion that since the BEPS Action Plan attempted to fight double non-taxation, but without changing the balance between source and residence principle, it could result in increasing tax collection in the residence country. As Argentina is an importer of capital, tax collection does not benefit from the application of the residence principle.

The inputs of the AFIP to the BEPS Action Plan are confidential. However, the AFIP has pointed out that the discussion of the transfer pricing aspects of commodity transactions was more relevant for the AFIP than, for example, the discussion of cost contribution arrangements, and for this reason, the participation of AFIP was more active in the discussion of the former than the latter.

In relation to the local application of country-by-country $(\mathrm{CbC})$ reporting, the AFIP identified in 2015 only 10 local headquarters that would be required to comply with such reporting if the $€ 750 \mathrm{~m}$ threshold is applied. However, regulations for $\mathrm{CbC}$ reporting have not been enacted yet, and at least a general resolution needs to be enacted by the AFIP in order to request $\mathrm{CbC}$ reporting from local headquarters. In November 2015, before the presidential change, the intention was to prepare the necessary regulatory changes to request the $\mathrm{CbC}$ reports and Master File from local MNEs' headquarters, and to request such files from local affiliates in the event that they were not provided by the jurisdiction of the parent company. ${ }^{95}$

The AFIP has shown itself prepared to introduce the necessary changes in local documentation requirements ${ }^{96}$ in order to follow the G20/OECD/BEPS Action Plan recommendations in relation to the Local File and Master File. It is also very interested in the potential for understanding the whole value chain that will be provided by use of the Master File and $\mathrm{CbC}$ reports.

See the Argentine Tax Director's response to the comments by local taxpayers on the differences between the valuation of commodity exports according to the Argentine Sixth Method and the method proposed in the G20/OECD/BEPS Action Plan, available at www.cronista.com/columnistas/Contribuyentes-argentinosvalidan-la-aplicacion-del-sexto-metodo-20151008-0047.html (accessed 7 December 2016). Ibid.

This information was obtained from a survey on $\mathrm{CbC}$ reporting conducted by CIAT with the collaboration of Andres Knobel and Sol Picciotto.

96 Appendix 2 provides a brief description of local transfer pricing documentation requirements.
} 
Regarding other action points, in relation to Action 5 on harmful tax practices, Argentina considers that it is already engaged in transparency and information exchange, and that it does not have special tax regimes that it needs to change.

At different tax-related events in which the Argentine tax authorities participated in $2014,{ }^{97}$ they expressed their concerns relating to the mandatory mechanisms for arbitration of international tax disputes, and expressed the view that Argentina would not accept arbitration. ${ }^{98}$

However, as of 2016 a new elected government has been in place, and decisions relating the application of the BEPS Action Plan may be affected by this political change.

\section{Conclusions}

The analysis of regulatory changes in relation to transfer pricing in Argentina shows that since 1976, the arm's length principle of transfer pricing has been explicitly adopted in the country. Before that, and for an extended period, the economic reality principle was generally used for the interpretation of transactions within economic groups, with the perspective that it was economic substance, rather than contractual forms, that was relevant.

The principle of economic reality, as interpreted by the Parke Davis doctrine and the rulings by the CSJN between 1972 and 1974, and as reflected in the LIG of 1973, is still formally in place. However, changes were made to introduce the arm's length principle, which were gradually consolidated further, and over time the verdicts have become more and more favourable to MNEs. The result is a contradictory and confused situation with a lack of clarity for taxpayers and the AFIP alike.

Regarding transactions in goods, the first article specifically aimed at tackling transfer mispricing was initially introduced into Argentine legislation as a consequence of the findings on the Vestey case revealed by a Senate Commission in 1934, which showed that the Anglo-Argentinean meat-packing company was paying no taxes in either Argentina or England. Thus, from 1943, and until the introduction of the Sixth Method for commodity valuation in 2003 , exports and imports were valued using the wholesale price at destination and origin, respectively (locally referred to as the 'exports and imports clause'). Following this evolution, the Sixth Method can be said to be a much less restrictive application of the exports and imports clause.

In order to understand all of these changes, Argentina's case needs to be analysed in an international context. The utilisation of the arm's length standard, the independent entity criteria and the replacement of the source for the resident principle in most DTTs has been a growing tendency throughout the world. These changes have taken place along with a growing financiarisation of the global economy and a growing trend towards favouring the movement of capital throughout countries. ${ }^{99}$

III Jornadas de Tributacion Internacional organised by the Asociacion Argentina de Estudios Fiscales (AAEF) Buenos Aires, 6 and 7 November 2014; Mesa Redonda Regional sobre Tributaciòn Internacional: Desafios y perspectivas de las tributación internacional en América Latina y el Caribe, organised by LATINDADD, CIAT and AFIP, Buenos Aires, 26 and 27 August 2014

At the AAEF event of November 2014 cited above, Antonio Figueroa (former National Director of Taxes in the Ministry of Economy in Argentina, serving from 1989-1997, and Director of International Tax Relations from 1972-1989) criticised arbitration as a means for giving advantages to foreign investment over local investment.

See Figueroa 2014 for an analysis of these ideas in the context of the BEPS Action Plan. 
The consequences of these regulatory changes have been that lately, more and more cases are being disputed at different court levels, and tax authorities seem to find it increasingly difficult to challenge MNEs' transfer pricing manipulation schemes and support their arguments in courts of law.

Argentina has actively participated in the G20/OECD BEPS Action Plan discussions but, like many developing countries, has expressed its concerns that this plan would result in increasing tax collection in the countries of residence rather than in the developing ones. In any case, and even though the AFIP has expressed that it considers that the outcomes of the BEPS Action Plan should be understood as recommendations and not as rules to be followed (except in those cases in which minimum commitment was specified), it is likely to comply with most suggested regulatory changes. It is likely to start with those relating to Action 13 on transfer pricing documentation and country-by-country reporting, since it finds that such information could prove very useful in order to have a better understanding of MNEs' economic activities. 


\section{Appendices}

\section{Appendix 1 Summary table with transfer pricing-related court decisions ${ }^{100}$}

\begin{tabular}{|c|c|c|c|c|c|}
\hline Company & $\begin{array}{l}\text { Ruling } \\
\text { from }\end{array}$ & $\begin{array}{l}\text { Fiscal } \\
\text { year in } \\
\text { question }\end{array}$ & $\begin{array}{l}\text { Date of last } \\
\text { ruling }\end{array}$ & $\begin{array}{l}\text { Result in } \\
\text { favour of }\end{array}$ & Details \\
\hline $\begin{array}{l}\text { Refinerías de } \\
\text { Maíz }\end{array}$ & CSJN & $\begin{array}{l}1954- \\
1956\end{array}$ & 10 June 1964 & $\begin{array}{l}\text { Tax } \\
\text { authority }\end{array}$ & $\begin{array}{l}\text { The CSJN held in the case of Refinerías de Maíz that royalty payments should be considered contributions to } \\
\text { the income of the parent company (dividend payments) and could not be deducted for income tax calculation } \\
\text { purposes, since the parent company owned } 96 \text { per cent of the stocks of the Argentine affiliate, and for that } \\
\text { reason, such enterprises could not be considered to be independent. The underlying argument was the } \\
\text { economic reality principle. }\end{array}$ \\
\hline SIA S.A. & CSJN & & 9 June 1967 & $\begin{array}{l}\text { Tax } \\
\text { authority }\end{array}$ & $\begin{array}{l}\text { SIA S.A. declared losses on the export of horses to Peru, Venezuela and the United States of America. The } \\
\text { Direcciòn General Impositiva (DGI) }{ }^{101} \text { challenged this under the export and import clause and calculated the } \\
\text { 'wholesale price' based on data from foreign magazines on the horse business, which explicitly referred to } \\
\text { the horses of the taxpayer and the transactions involved in this case. }\end{array}$ \\
\hline $\begin{array}{l}\text { Le Carbone } \\
\text { Lorraine S.A. }\end{array}$ & TFN & 1960 & $\begin{array}{l}29 \\
\text { September } \\
1969\end{array}$ & Taxpayer & $\begin{array}{l}\text { This case focused mainly on the tax classification of certain amounts paid to Sociéte Le Carbone Lorraine de } \\
\text { Paris, France, the main shareholder of the appellant Le Carbone Lorraine S.A., which were classified by the } \\
\text { latter as royalties, and by the tax authority as income transferred abroad. The TFN ruled in favour of the } \\
\text { taxpayer, finding that although the French company Le Carbone Lorraine was the main shareholder of the } \\
\text { appellant Le Carbone Lorraine S.A., its participation amounted to only } 70 \text { per cent of the local entity's total } \\
\text { stocks, so they could not be considered as being part of the same economic group. }{ }^{102}\end{array}$ \\
\hline $\begin{array}{l}\text { Productos } \\
\text { Químicos CIBA } \\
\text { SAIC }\end{array}$ & TFN & $\begin{array}{l}1962 \text { and } \\
1963\end{array}$ & $\begin{array}{l}9 \text { February } \\
1972\end{array}$ & $\begin{array}{l}\text { Taxpayer/ } \\
\text { tax authority }\end{array}$ & $\begin{array}{l}\text { The case concerned royalty and interest payments made to related parties. In relation to royalty payments, } \\
\text { the court ruled against the tax authority, observing that it could not be concluded that a foreign headquarters } \\
\text { and a local affiliate form part of an economic unit; and that it could not be concluded that the existence of } \\
\text { such a relationship invalidates the license contracts for the use of brands and patents. In relation to the } \\
\text { interest payments, the court ruled against the taxpayer because of the absence of an agreement describing } \\
\text { the conditions of the financial transaction. }\end{array}$ \\
\hline Parke Davis & CSJN & $\begin{array}{l}1963- \\
1967\end{array}$ & 31 July 1973 & $\begin{array}{l}\text { Tax } \\
\text { authority }\end{array}$ & $\begin{array}{l}\text { The CSJN held that in spite of its apparent juridical independence, the local company is organically related to } \\
\text { the foreign company because of its financial incorporation into the dominating entity and the royalty payment } \\
\text { was therefore considered to be a capital transfer (dividend payment), and could not be deducted for income } \\
\text { tax calculation purposes. }\end{array}$ \\
\hline $\begin{array}{l}\text { Compañía Swift } \\
\text { de La Plata S.A. } \\
\text { Frigorífica }\end{array}$ & CSJN & & $\begin{array}{l}4 \text { September } \\
1973\end{array}$ & $\begin{array}{l}\text { Tax } \\
\text { authority }\end{array}$ & $\begin{array}{l}\text { The CSJN held that since the creditors and debtors were divisions of the same company the 'reality of the } \\
\text { loan agreements' meant that the legal relations lack the basic duality between creditor and debtor that all } \\
\text { agreements presuppose; for this reason, the interest payments could not be considered deductible and }\end{array}$ \\
\hline
\end{tabular}

100 There is no official listing of transfer pricing disputes, so this list should be seen as the best compilation effort that could be made using publicly available information, the gatherings of other authors and interviews held.

101 Until 1997, the DGI (in English - General Directorate of Taxation) and the Dirección General Aduanera (DGA - General Directorate of Customs) were two separate institutions. In 1997 they unified under the AFIP.

102 Under Section 87 of the Income Tax Law, 'a group of companies is presumed to exist in the case of companies' reorganisations, whenever 80 per cent or more of the new company's corporate capital belonged to the owner or partners of the reorganised company'. Decree 10.609/1956 increased the percentage to 80 per cent; previously, it was 50 per cent. 


\begin{tabular}{|c|c|c|c|c|c|}
\hline & & & & & should be treated as dividends. \\
\hline Mellor Goodwin & CSJN & $\begin{array}{l}1960- \\
1965\end{array}$ & $\begin{array}{l}18 \text { October } \\
1973\end{array}$ & Taxpayer & $\begin{array}{l}\text { The CSJN ruled holding that within an economic group the entities could not be said to have performed } \\
\text { purchase-sale operations among themselves, but had merely transferred merchandise among related } \\
\text { entities, and sales taxes could only be collected on sales to third parties. }\end{array}$ \\
\hline $\begin{array}{l}\text { Rheinstahl } \\
\text { Hanomag Cura } \\
\text { S.A. }\end{array}$ & CSJN & & $\begin{array}{l}17 \text { December } \\
1973\end{array}$ & $\begin{array}{l}\text { Tax } \\
\text { authority }\end{array}$ & $\begin{array}{l}\text { The CSJN ruled holding that interest payments relating to financing for an import of goods should not be } \\
\text { considered as part of the price of the goods under Article } 9 \text { (the import and export clause) of the LIG, and } \\
\text { should be treated as of Argentine source. Such interest should not be included as costs in the tax accounts of } \\
\text { the local entity. The economic reality principle was thus applied even when there was no economic relation } \\
\text { between the parties, based on the implied economic relation in the import-export clause. }\end{array}$ \\
\hline $\begin{array}{l}\text { Ford Motor } \\
\text { Argentina S.A. }\end{array}$ & CSJN & $\begin{array}{l}1962- \\
1967\end{array}$ & 2 May 1974 & $\begin{array}{l}\text { Tax } \\
\text { authority }\end{array}$ & $\begin{array}{l}\text { In the case of Ford Motor Argentina S.A., relating to intragroup loans, the CSJN ruled stating that 'in the } \\
\text { hypothesis of an economic unit or equivalent situations, the payments between the entities within such an } \\
\text { economic unit should be ruled by the principles of contribution and utility' (i.e. they should be considered as } \\
\text { capital contributions or dividends). }\end{array}$ \\
\hline $\begin{array}{l}\text { Petroquímica } \\
\text { Argentina S.A. }\end{array}$ & CSJN & & 17 May 1977 & Taxpayer & $\begin{array}{l}\text { In the case of Petroquímica Argentina S.A., the CSJN ruled in favour of the taxpayer. This case was } \\
\text { considered to be an 'anti-Mellor Goodwin ruling', since the CCAF had referred to the Mellor Goodwin ruling } \\
\text { when discussing the issue of double taxation, though arguing that because Petroquímica had passed the tax } \\
\text { to the third party there was no double taxation. The CSJN ruled in favour of the taxpayer on the grounds that } \\
\text { there had been double taxation. }\end{array}$ \\
\hline $\begin{array}{l}\text { Eduardo } \\
\text { Loussinian } \\
\text { S.A.C.I.F.I.A. }\end{array}$ & CSJN & $\begin{array}{l}1974 \text { and } \\
1975\end{array}$ & $\begin{array}{l}20 \\
\text { September } \\
1983\end{array}$ & Taxpayer & $\begin{array}{l}\text { The Tax Administration Department had challenged what seemed to be schemes to over-invoice imports, } \\
\text { based on Article } 8 \text { of the LIG. But the CSJN found that there was no ownership relationship between the } \\
\text { entities, and the profit could not be said to be of Argentine source. }\end{array}$ \\
\hline $\begin{array}{l}\text { Kellogg Co. } \\
\text { Argentina } \\
\text { S.A.C.I. y F. }\end{array}$ & CSJN & $\begin{array}{l}1970 \\
1971 \text { and } \\
1972\end{array}$ & $\begin{array}{l}26 \text { February } \\
1985\end{array}$ & $\begin{array}{l}\text { Tax } \\
\text { authority }\end{array}$ & $\begin{array}{l}\text { Kellogg Co. Argentina was a manufacturer company controlled by Kellogg Co. from the United States of } \\
\text { America (USA), and Kellogg Sales, a branch of Kellogg Co. from the USA that had been created in order to } \\
\text { exclusively distribute the goods manufactured by Kellogg Co. Argentina. Kellogg Sales paid Kellogg Co. } \\
\text { Argentina on a cost plus } 4 \text { per cent basis for the goods purchased to be sold in the local market. Kellogg Co. } \\
\text { Argentina had operations with related parties abroad referring to royalty, interest and technical services; it } \\
\text { paid these, and afterwards forwarded such charges to Kellogg Sales. The ruling by the CSJN explicitly } \\
\text { recognised the Parke Davis doctrine and applied the economic reality principle to the transactions between } \\
\text { the related entities within the country. }\end{array}$ \\
\hline $\begin{array}{l}\text { Aerolíneas } \\
\text { Argentinas S.A. }\end{array}$ & TFN & $\begin{array}{l}1994 \\
1995 \\
1996 \\
1997 \\
1998 \\
1999\end{array}$ & 12 May 2004 & $\begin{array}{l}\text { Tax } \\
\text { authority }\end{array}$ & $\begin{array}{l}\text { Aerolíneas Argentinas appealed the decision of the tax authority to charge the withholding tax in relation to } \\
\text { the payments made to a foreign beneficiary (for the Amadeus System used for bookings). Aerolíneas } \\
\text { Argentinas considered such withholding tax to be wrongly calculated since the service had been rendered } \\
\text { abroad, and appealed the fine for non payment that had been applied by the AFIP. The TFN confirmed the } \\
\text { tax adjustment made by the tax authority, but ruled in favour of the taxpayer in relation to the fines. }\end{array}$ \\
\hline $\begin{array}{l}\text { Compañía } \\
\text { Procesadora de } \\
\text { Carnes S.A. }\end{array}$ & TFN & 2002 & $\begin{array}{l}5 \text { November } \\
2004\end{array}$ & Taxpayer & $\begin{array}{l}\text { The tax authority had applied a fine, based on Article } 45 \text { of the Federal Act on Tax Procedures (No. 11.683), } \\
\text { for having presented an incorrect transfer pricing sworn declaration. Compañia Procesadora de Carnes } \\
\text { appealed and the TFN ruled in its favour, observing that the price difference affected only } 3.83 \text { per cent of the } \\
\text { declared tax, and such a mistake was excusable considering the novelty of the topic and the difficulties } \\
\text { encountered by taxpayers in complying with such extensive and changing legislation, with scarce case law to } \\
\text { serve as a guide in dubious cases. }\end{array}$ \\
\hline $\begin{array}{l}\text { Laboratorios } \\
\text { Bagó S.A. }\end{array}$ & TFN & $\begin{array}{l}1997 \text { and } \\
1998\end{array}$ & $\begin{array}{l}16 \text { November } \\
2006\end{array}$ & Taxpayer & $\begin{array}{l}\text { Laboratorios Bagó S.A. exported finished and semi-finished manufactured products to foreign subsidiaries. } \\
\text { The tax authority adjustment had been made on the basis of, among others, the difference between the price } \\
\text { charged by Bagó to local independent purchasers and the lower price agreed between Bagó Argentina and } \\
\text { its offshore associated enterprises. The taxpayer argued that, with regard to its export transactions, it only } \\
\text { performed 'contract manufacturer' activities. The tax court ruled in favour of the taxpayer, considering that the }\end{array}$ \\
\hline
\end{tabular}




\begin{tabular}{|c|c|c|c|c|c|}
\hline & & & & & $\begin{array}{l}\text { tax authority had failed to meet the burden of proof relevant for a transfer pricing dispute. (Baistrocchi 2012; } \\
\text { PwC 2012) }\end{array}$ \\
\hline Surmar S.A. & TFN & 2002 & 6 March 2007 & $\begin{array}{l}\text { Tax } \\
\text { authority }\end{array}$ & $\begin{array}{l}\text { Surmar had rectified its transfer pricing declaration after the AFIP had detected differences in its meat export } \\
\text { prices, and hidden interest charges. For that reason, the tax authority claimed that a fine was applicable, and } \\
\text { the TFN ruled in favour of the tax authority under the regulations in place. }\end{array}$ \\
\hline $\begin{array}{l}\text { Compañía } \\
\text { Ericsson } \\
\text { S.A.C.I. }\end{array}$ & TFN & $\begin{array}{l}1996 \text { and } \\
1997\end{array}$ & $\begin{array}{l}15 \text { August } \\
2007\end{array}$ & Taxpayer & $\begin{array}{l}\text { The local entity had taken out a loan of } 12 \text { million Argentine Pesos }{ }^{103} \text { from Ericsson Treasury Services of } \\
\text { Sweden, the conditions of which were agreed in an internal company memorandum. The tax authority } \\
\text { questioned the loan based on the informality with which it had been made by the company (via a memo) and } \\
\text { the level of thin capitalisation. The TFN did not accept any of the tax authority's arguments and ruled in favour } \\
\text { of the taxpayer. The court quoted paragraph } 1.52 \text { of the OECD Transfer Pricing Guidelines: 'Where no written } \\
\text { terms exist, the contractual relationships of the parties must be deduced from their conduct and the economic } \\
\text { principles that generally govern relationships between independent enterprises.' The court held that the } \\
\text { conduct of the entities involved in this transaction does not justify inferring tax avoidance behaviour, since the } \\
\text { relevant loan was replaced by another loan under similar conditions from a local, independent financial } \\
\text { institution. (Baistrocchi 2012) }\end{array}$ \\
\hline Litoral Gas SA & $\begin{array}{l}\text { Ruling by } \\
\text { TFN ratified } \\
\text { by the } \\
\text { CCAF }\end{array}$ & 1999 & 17 April 2008 & $\begin{array}{l}\text { Tax } \\
\text { authority }\end{array}$ & $\begin{array}{l}\text { Neither the TFN nor the CCAF accepted the deductibility of interest because the actual date of the loan } \\
\text { contract could not be found. }\end{array}$ \\
\hline $\begin{array}{l}\text { Volkswagen } \\
\text { Argentina S.A. }\end{array}$ & TFN & 1998 & $\begin{array}{l}11 \text { December } \\
2009\end{array}$ & Taxpayer & $\begin{array}{l}\text { A company resident in Brazil acquired products from Volkswagen Argentina S.A., and sold them to } \\
\text { Volkswagen do Brasil. The AFIP considered that the three were related parties, and that Article } 8 \text { of the LIG } \\
\text { should be applied and the prices compared with the wholesale price in the jurisdiction of destination, and if } \\
\text { such prices were not found, the wholesale price in the seller's jurisdiction, which in this case would be the } \\
\text { price of the local car dealers. In this way, the tax authority found that the export prices for cars sold to } \\
\text { Volkswagen do Brazil were significantly lower than those in the local market, and therefore the local market } \\
\text { price should be taken as valid. Volkswagen Argentina complained, arguing that the export prices were } \\
\text { calculated in order to comply with the import quota, }{ }^{104} \text { and that it would make no sense to reduce such export } \\
\text { prices since that would reduce the value that the company would be able to import in order to comply with } \\
\text { local legislation. Also, that that there was a wholesale price in Brazil that the AFIP made no effort to find. The } \\
\text { court considered that certain clauses evidenced the control that Volkswagen Argentina S.A. and Volkswagen } \\
\text { do Brasil exerted on the third party. As such, the tax court concluded that the operations should be } \\
\text { considered as having been conducted between related parties. However, the tax court observed that the } \\
\text { administrative court ignored Article } 8 \text { and applied Article } 11 \text { of the regulatory decree without giving any } \\
\text { reason for not applying the wholesale prices in the country of destination (Brazil) (PwC } 2012 \text { ). It also held that } \\
\text { the double tax treaty with Brazil should be applied and that a thorough analysis of the circumstances } \\
\text { surrounding the pricing should be made, rejecting the proposal of the AFIP to directly apply the difference } \\
\text { between the export price and the local price. (D'Agostino 2010) }\end{array}$ \\
\hline $\begin{array}{l}\text { Aventis Pharma } \\
\text { S.A. }\end{array}$ & TFN & 2000 & $\begin{array}{l}26 \text { February } \\
2010\end{array}$ & Taxpayer & $\begin{array}{l}\text { Aventis Pharma was an Argentine subsidiary of a US pharmaceutical enterprise. The AFIP had questioned } \\
\text { the choice of Bentley Pharmaceuticals Inc., a US company, as an independent comparable for the } \\
\text { manufacturing for local sales segment, because it submitted accounts showing recurring losses, and } \\
\text { including this company 'among the comparables has the effect of inappropriately reducing the revenue ratio }\end{array}$ \\
\hline
\end{tabular}

Equivalent to US\$12 million at the time.

The Argentina automotive regulations require imports-exports compensation; this means that the value of the automotive imports needs to be compensated with exports of an equivalent value. 


\begin{tabular}{|llll|l|}
\hline Lineas Aereas & TFN & 1997, & 14 April 2010 & Taxpayer \\
Privadas & & 1998, & & \\
Argentinas S.A. & & 2000, & & \\
\hline $\begin{array}{l}\text { Volkswagen } \\
\text { Argentina S.A. }\end{array}$ & TFN & 1999 & 12 July 2010 & Taxpayer \\
\hline
\end{tabular}
of the comparables when applying the Transactional Net Margin Method (TNMM)'. However, the taxpayer
appealed the administrative court decision, arguing that Bentley Pharmaceuticals Inc. was an independent company that operated under market conditions, and that it considered 'the exclusion of a comparable for the mere fact that it is showing recurrent losses is arbitrary and unfounded', alleging that 'such a reason for exclusion is not found in the relevant legislation nor in the OECD Guidelines'. The AFIP argued that the OECD Guidelines did not have legislative status in Argentina. The TFN ruled in favour of the taxpayer, stating that the tax authority claim was based on its disagreement with the transfer pricing report presented by the appellant, and no results obtained from any systematic research had been attached which could base the rejection on serious conclusions rather than those of mere rhetorical argument; also that even if the OECD Guidelines did not have legislative status, they could be used in order to fill in the gaps where the Argentine legislation did not have a stated position. The case also referred to two other issues, the first being whether the results of the comparables should be adjusted in order to consider the discounts given by Aventis Pharma in sales to a government agency; the second, the treatment as income of the payments for research and development. Both these arguments were also lost by the tax authority.

The AFIP applied income tax to the payments received by the foreign provider of the Amadeus System in relation to the bookings made for Lineas Aereas Privadas Argentinas, and paid by this airline company to the foreign service provider. The TFN held that the payments made to the provider of the Amadeus System we foreign service provider. The TFr of foreign source.

The AFIP argued that Volkswagen Argentina had concluded similar export transactions with related parties and unrelated parties, obtaining different results from such transactions. Volkswagen Argentina had reduced its production by 33.4 per cent in 1999, and had laid off 500 employees between February 1999 and February 2000; declared 7.8 million Argentine Pesos as bad debt; ${ }^{105}$ and had made idle capacity, dismissal compensation, and bad debt adjustments on the results obtained by the independent comparables chosen. The tax court decided in favour of Volkswagen, arguing that the taxpayer's transfer pricing study reversed the burden of proof onto the tax authority. (Baistrocchi 2012)

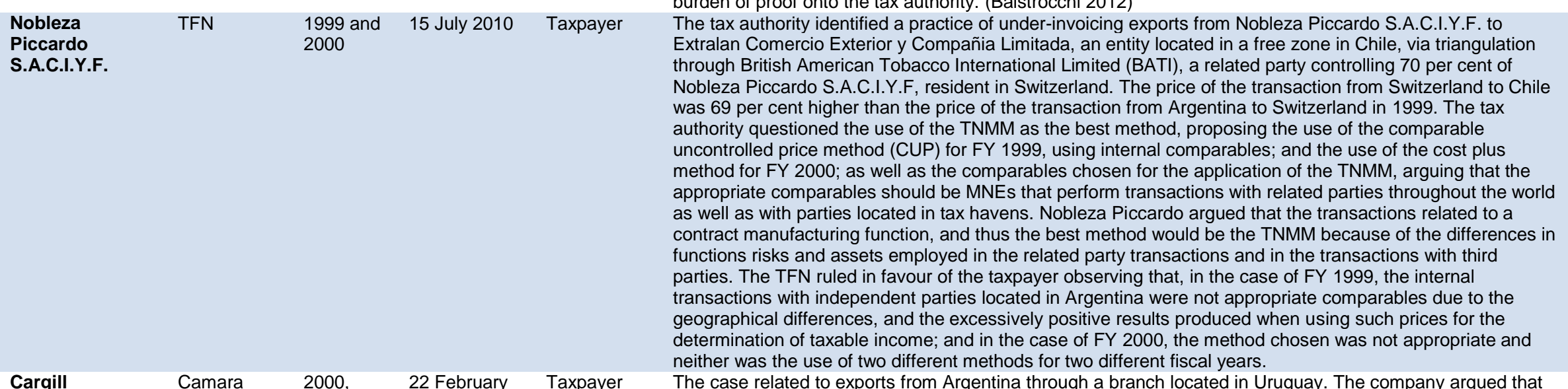

105 Equivalent to US\$7.8 million at the time. 


\begin{tabular}{|c|c|c|c|c|c|}
\hline S.A.C.E.I. & $\begin{array}{l}\text { Nacional de } \\
\text { Apelaciones } \\
\text { en lo Penal } \\
\text { Tributario } \\
\text { (CNAPT - } \\
\text { National } \\
\text { Appeal } \\
\text { Court for } \\
\text { Tax Crimes) }\end{array}$ & $\begin{array}{l}2001, \\
2002, \\
2003\end{array}$ & 2011 & & $\begin{array}{l}\text { the prices from Montevideo were settled with different importers throughout the world and that these prices } \\
\text { were agreed verbally by telephone or through different types of mail, in relation to the demand and supply at } \\
\text { the date of these communications, and that this is the reason why the prices were different from those at the } \\
\text { shipping date taken by the tax authority. Cargill's directors were charged for the crime of tax evasion, and the } \\
\text { Court on Economic Crimes ruled against them on the grounds that there was no definitive date of agreement; } \\
\text { but on appeal to the CNAPT that court ruled in their favour, considering that the pricing methodology involved } \\
\text { had not always resulted in a lower export price. }\end{array}$ \\
\hline YPF S.A. & TFN & 2000 & $\begin{array}{l}15 \text { December } \\
2011\end{array}$ & Taxpayer & $\begin{array}{l}\text { The tax authority had questioned loan transactions performed by YPF with its related parties (YPF Gas, } \\
\text { Maleic and OPESSA), arguing that the payments received by the taxpayer in the form of interest had been } \\
\text { lower (or zero in the transaction with OPESSA) than they should have been. However, the TFN ruled against } \\
\text { the tax authority on regulatory grounds, i.e. it observed that the regulations that served as a basis for the tax } \\
\text { authority decision had been inappropriately used. The tax authority had also questioned the gasoil and LPG } \\
\text { export prices based on Article } 12 \text { of General Resolution (AFIP) } 1122 / 2001.106 \text { However, the TFN ruled against } \\
\text { the use of such regulations on the grounds that they had been published after the fiscal year under review. } \\
\text { (Cronista 2012) }\end{array}$ \\
\hline $\begin{array}{l}\text { Hoteles } \\
\text { Sheraton de } \\
\text { Argentina } \\
\text { S.A.C. }\end{array}$ & TFN & $\begin{array}{l}2000, \\
2001, \\
2002\end{array}$ & 6 March 2012 & Taxpayer & $\begin{array}{l}\text { The tax authority objected to the expenses deducted in relation to the Starwood Preferred Guest (SPG) } \\
\text { Program, a frequent traveller programme managed by Starwood Hotels and Resorts Worldwide, Inc., in the } \\
\text { USA, the controlling company of all the entities that are shareholders of Hotels Sheraton de Argentina S.A.C. } \\
\text { The company had asked for the deductibility of such charges in a binding consultation }{ }^{107} \text { made on } 12 \text { August } \\
\text { 1999, which the AFIP had refused on the grounds that it could not be determined how such charges were } \\
\text { due to obtaining, maintaining and preserving profits of Argentine source. The court ruled in favour of the } \\
\text { taxpayer. }\end{array}$ \\
\hline $\begin{array}{l}\text { Boehringer } \\
\text { Ingelheim S.A. }\end{array}$ & TFN & 1999 & 13 April 2012 & Taxpayer & $\begin{array}{l}\text { The tax authority objected, based on the transfer pricing documentation, to: 1) the comparable companies } \\
\text { chosen; 2) averaging the results of the tested parties of the years } 1997,1998 \text { and } 1999 \text { and those of the } \\
\text { comparable companies of the years } 1996,1997 \text { and } 1998 \text {, all for the purpose of analysing the results of the } \\
\text { company for the fiscal year } 1999 ; 3 \text { ) the functional analysis performed in which the activities of the company } \\
\text { were segmented into different activities and functions; } 4 \text { ) the choice of the financial indicators; } 5 \text { ) the fact that } \\
\text { there was no country risk adjustment made. The TFN found that the tax authority had not presented sufficient } \\
\text { arguments to defend its position and that its position was wrong. }\end{array}$ \\
\hline Akapol S.A. & CSJN & $\begin{array}{l}1997- \\
2000\end{array}$ & 3 May 2012 & Taxpayer & $\begin{array}{l}\text { In the case of Akapol S.A. against the tax administration relating to loans provided to entities alleged to be } \\
\text { related by the tax authority, the latter proposed that such loans could be considered as a transfer of capital } \\
\text { disguised as a loan. However, the CSJN ruled that the loans related to the commercial activity of the } \\
\text { company and that the interest rate obtained by Akapol S.A. was higher than the commercial bank rate; hence } \\
\text { it was not necessary to analyse whether the entities were related parties belonging to the same economic } \\
\text { group or not, or whether the regulations relating to related parties were applicable. }\end{array}$ \\
\hline $\begin{array}{l}\text { Volkswagen } \\
\text { Argentina S.A. }\end{array}$ & TFN & 2001 & $\begin{array}{l}29 \text { October } \\
2012\end{array}$ & Taxpayer & $\begin{array}{l}\text { Volkswagen Argentina's debt to its controlling company, Volkswagen A.G., had been written off. The AFIP } \\
\text { argued that this debt should have been considered as a capital transfer, affecting the accumulation of } \\
\text { negative results for the purpose of the calculation of the taxable base. The AFIP also questioned the use of } \\
\text { several years of income statements of the comparable companies. The court ruled in favour of the taxpayer. }\end{array}$ \\
\hline
\end{tabular}

106 Article 12 of General Resolution 1122/2001 refers to the use of the interquartile range.

The binding consultations regime in Argentina is ruled by the AFIP's General Resolution 1948 of 2005 and consists of all technical-legal consultations made to the AFIP in relation to the determination of taxes and social security resources. The results of such binding consultations have to be considered in case of a tax audit. 
xported commodities (cereals and oils) through intermediaries resident in tax havens and considered that its export prices should be based on the export prices at the date of the agreement. Nidera argued that it sold its products to trading companies and that the trader was responsible for the exchange rate risk as well as the risk associated with the product quality, and the distribution and transport functions. The tax authority observed that the agreements did not have a specific date or place of settlement; there was no identification of the signatories of the agreement; the agreements had not been registered; and that at the dates chosen by the taxpayer for settling the price, such prices were systematically lower than those in place at the shipping date. However, Nidera argued that it was not until April 2002 that the requirement to register agreements with the Secretary of Agriculture was introduced. ${ }^{108}$ The case discussed whether the Sixth Method, Article 8 of the LIG, or the CUP method should have been applied. The Sixth Method was disregarded because it was not applicable at the time of the transactions. Article 8 was disregarded because there was no information on the wholesale price at the jurisdiction of destination. The tax authority then suggested the application of the CUP method (Article 15 of the LIG) using the prices published by the Secretary of Agriculture in Argentina at the shipping date, based on the analysis of the behaviour of other comparable companies (Alfred C. Toepfer and La Plata Cereal S.A.), in which the prices had been settled using the quotes published by the Secretary of Agriculture on such a date. The TFN ruled in favour of the tax authority and the CCAF upheld the decision of the TFN. The CCAF also held that the burden of proof of showing what independent parties had done fell on the taxpayer.

\begin{tabular}{|c|c|c|c|c|}
\hline $\begin{array}{l}\text { Oleaginosa } \\
\text { Moreno } \\
\text { S.A.C.I.F.I.A }\end{array}$ & TFN & 1999 & $\begin{array}{l}9 \text { September } \\
2014\end{array}$ & $\begin{array}{l}\text { Taxpayer/ } \\
\text { tax authority }\end{array}$ \\
\hline
\end{tabular}

Oleaginosa Moreno exported commodities to Atlantic Oils \& Meals (a related party resident in Switzerland), priced free on board (FOB), at international prices on the contract date. The invoice date was relatively close to the shipping date, but the price reflected in the invoice was based on a prior contract, which did not have a specific date. In the transfer pricing documentation presented by the taxpayer, Deloitte used the CUP method to validate Oleaginosa Moreno's prices, comparing the company's averaged prices with the ones published by the Secretary of Agriculture for the invoice date. The tax authority made the tax adjustments based on the highest price (referring to Article 8 of the LIG, although it did not use the prices at destination and nor did the taxpayer) published by the Secretary of Agriculture between the invoice and the shipping date for the commodities exported to Atlantic Oils \& Meals, in a transaction by transaction analysis. The tax authority also observed that the exports made to an independent party in Chile had been priced using the quotes published by the Secretary of Agriculture for the invoice date. The adjustments made by the tax authority reduced the tax loss carry forward of the taxpayer. The taxpayer questioned the use of the shipping date, alleging that the Sixth Method had been applied retroactively; and it objected to the internal comparables (the transactions with the independent party in Chile) used, alleging that the transactions had significant differences for which with the independent party in Chile) used, alleging that the transactions had significant differences for which no adjustments had been made. The TFN found that there had not been a retroactive application of the Sixt analysis did not indicate that the price to be used should be that of the international exchange quoted price at the shipping date, so a valid quoted price at the date for the contract could be used. The TFN also observed that the transactions with the independent party in Chile could not be used as a reference for the date to be used due to the significant differences they had with the transactions with related parties. Nevertheless, the TFN ruled in favour of the tax authority in relation to the use of a transaction by transaction analysis, instead of the average global analysis employed by the taxpayer.

Cisco Systems The TFN $1999 \quad 14$ April 2015 Taxpayer/

Cisco Systems Argentina's main activity was the promotion and marketing of all the products of Cisco 2012. But in

tax authority

Law 21.453 of 1976 , on regulations for the exportation of agricultural products, and this law's modifications. 


\begin{tabular}{|c|c|c|c|c|c|}
\hline & $\begin{array}{l}\text { 2014, the } \\
\text { CCAF left } \\
\text { such ruling } \\
\text { without } \\
\text { effect after } \\
\text { the appeal } \\
\text { of the tax } \\
\text { authority } \\
\text { and asked } \\
\text { the TFN for } \\
\text { a new } \\
\text { ruling. }\end{array}$ & & & & $\begin{array}{l}\text { employees took technical training courses in the United States, other Latin American countries and Europe. } \\
\text { Also, Cisco Systems Argentina S.A. received as remuneration for the services rendered to Cisco Systems } \\
\text { Inc., a } 5 \text { per cent mark-up over the total costs incurred for rendering such services. The tax authority } \\
\text { challenged the deductibility of the expenses (intranet expenses with a related party in San Jose, USA; AT\&T } \\
\text { calling cards; system expenses hired by Cisco Systems Inc.; charges relating to technical training courses; } \\
\text { employees' mobile phone expenses, etc.). The tax authority alleged that it was not clear whether such } \\
\text { expenses benefited the local taxpayer or Cisco Systems Inc. It is worth noting that in this case the tax } \\
\text { authority questioned the expenses, but did not question the transfer pricing structure used by the company, } \\
\text { which could be classified as a contract provider of marketing services. The taxpayer alleged that the burden } \\
\text { of proof was on the tax authority. The TFN ruled, in } 2012 \text {, in favour of the taxpayer, using as a reference the } \\
\text { intragroup agreement. On appeal by the tax authority and at the request of the CCAF for a new ruling by the } \\
\text { TFN, the TFN in } 2015 \text { quoted in its ruling the recommendations in the OECD Guidelines for testing whether a } \\
\text { service had been rendered at arm's length, as well as those of the EU Transfer Pricing Forum; and accepted } \\
\text { that most of the charges were deductible, except for those relating to travel expenses exceeding the airplane } \\
\text { ticket. }\end{array}$ \\
\hline $\begin{array}{l}\text { Italtel S.P.A. } \\
\text { Sucursal } \\
\text { Argentina }\end{array}$ & TFN & 2000 & 20 April 2015 & $\begin{array}{l}\text { Taxpayer/ } \\
\text { tax authority }\end{array}$ & $\begin{array}{l}\text { The tax authority rejected the deductibility of the general expenses of the board of directors and central } \\
\text { administration, as well as direct production expenses, charged by the headquarters to the local entity, } \\
\text { challenging the relationship between such charges and the revenue obtained by the local branch. The TFN's } \\
\text { ruling quoted the observations made by Argentina to the OECD Model Tax Convention, in which Argentina } \\
\text { reserved the right to challenge the deductibility of expenses made abroad which cannot be reasonably } \\
\text { attributed to the activity performed by a permanent establishment (PE). The TFN then identified, based on } \\
\text { local legislation, and the OECD Model Tax Convention and its observations, the following factors which are } \\
\text { required for the deductibility of expenses incurred abroad: (i) necessary; (ii) needed to obtain, maintain and } \\
\text { conserve profits; (iii) linkage and reasonable linkage; (iv) effective connection; (v) existence of irrefutable } \\
\text { documentation; (vi) direct, necessary and reasonable correlation; (vii) reasonable attribution; (viii) economic } \\
\text { nexus; (ix) necessary, just and reasonable and duly proven; (x) the original receipts issued in the name of the } \\
\text { headquarters do not allow the local entity to make a tax deduction for them; (xi) effective proof of a direct } \\
\text { relation. From these principles, the TFN concluded that the direct production expenses of the products } \\
\text { imported by Italtel are deductible; but that the general expenses of the board of direction and administration } \\
\text { (which had been attributed to the local entity based on a sales formula) are not deductible. The Protocol } \\
\text { annexed to the Tax Treaty with Italy was also quoted by the TFN in its ruling, in which it is mentioned that the } \\
\text { expenses attributable to the PE are those directly related to the activity of the PE. (Laiun 2015) }\end{array}$ \\
\hline $\begin{array}{l}\text { Daimler } \\
\text { Chrysler } \\
\text { Argentina S.A. }\end{array}$ & CSJN & 1998 & 1 April 2014 & Taxpayer & $\begin{array}{l}\text { In Daimler Chrysler Argentina S.A., exports between Mercedes Benz Argentina and Mercedes Benz Brazil } \\
\text { were at a lower price than the wholesale price in Argentina. The TFN applied to all the exported units the } \\
\text { difference in value between the price of the car in the domestic market and the export price of the same car } \\
\text { (D'Agostino 2010). The TFN's ruling cited the cases of Parke Davis (1973) and Kellogg (1985), among } \\
\text { others, referring to the economic reality principle and the lack of independence of the affiliated company in } \\
\text { relation to the contracted operations with the foreign related party. The parties appealed to the CCAF (part of } \\
\text { the ruling had been against the tax authority's demands), which overruled the TFN, quashing the AFIP's } \\
\text { decision which had initially been appealed by the company. Both parties appealed to the CSJN, and the latter } \\
\text { confirmed the CCAF's decision. }\end{array}$ \\
\hline $\begin{array}{l}\text { Oleaginosa } \\
\text { Moreno } \\
\text { S.A.C.I.F.I.A }\end{array}$ & CSJN & 2000 & $\begin{array}{l}2 \text { September } \\
2014\end{array}$ & Taxpayer & $\begin{array}{l}\text { In the case of Oleaginosa Moreno (relating to the fiscal year 2000), an affiliated company of the Glencore } \\
\text { Group, the AFIP objected to the export price of commodities sold to Atlantic Oils \& Meals, a related party } \\
\text { located in Switzerland, because for } 36 \text { transactions the price had been documented as an average instead of } \\
\text { individually. The AFIP proposed that such prices should be calculated individually and in relation to the price } \\
\text { at the shipping date. }\end{array}$ \\
\hline
\end{tabular}




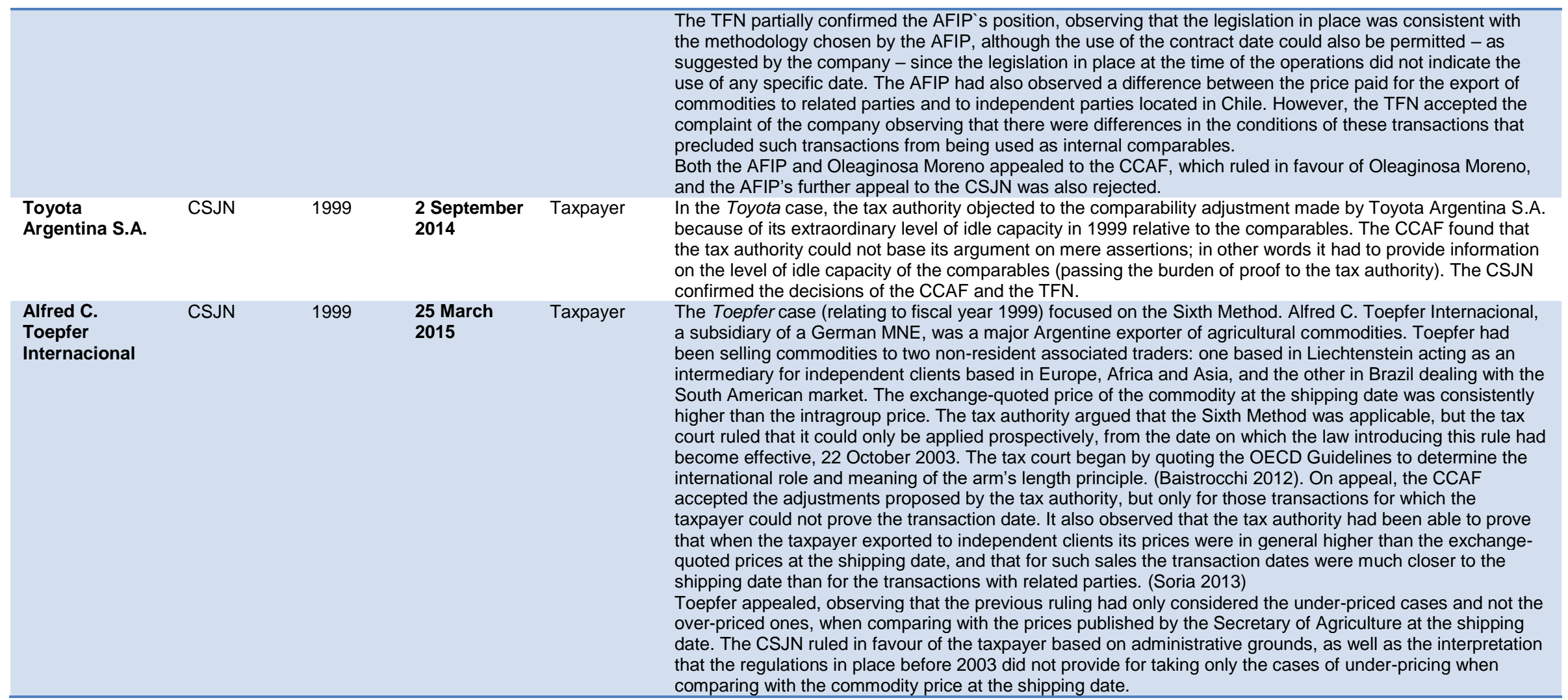

Source: Based on information extracted from BDO 2012; PwC 2012; Corti 1985, 2006, 2012; Martinez de Sucre and Corti 1976; Baistrocchi 2012; Baistrocchi ed. 2011; Grondona 2014; Laiun 2015; Soria 2013; and from the case rulings and legislation referred to. 


\section{Appendix 2 Information currently being requested in relation to transfer pricing ${ }^{109}$}

Regarding information that has to be provided to Argentine authorities for transfer pricing purposes, the legal basis is Article 6 of the (amended) AFIP Resolution $1122 / 2001 .^{110}$ This involves filing four forms $(969,741,742 \text { and } 867)^{111}$ about prices of imports and exports, describing the type of services, insurance, transport, etc. Additionally, a 'transfer pricing report' has to be filed, which should contain information about comparables and include, among others things, the identification of the foreign entities involved (in the informed/relevant transactions). ${ }^{112}$

However, pursuant to Article 8 and Annex IV of AFIP Resolution 1122/2001, information more closely related to country-by-country reporting has to be kept by the company. ${ }^{113}$ This information involves, among others, the multinational company's structure, including each company's functions, ownership, description, etc.; the foreign companies' financial statements (if they are relevant for the chosen transfer pricing method); the cost structure of the foreign related-company, etc.

In December 2013, AFIP General Resolution 3572 created a 'related party registry' and an 'informative regime for operations in the local market' for those taxpayers who register related parties abroad.

\section{Sanctions for non-compliance}

According to the amended Law $11.683,{ }^{114}$ Articles 38 and 39 , sanctions for not providing this information, or providing only partial information, could be up to 45,000 Argentine Pesos (ARS) (around £2,338), ${ }^{115}$ or up to ARS450,000 (around £23,385) if the company has an annual income above ARS10 million (around £519,660). Sanctions for not keeping the relevant information could be up to ARS45,000.

This section was elaborated based on the inputs of Andres Knobel.

Available at http://infoleg.mecon.gov.ar/infolegInternet/anexos/65000-69999/69608/texact.htm (accessed 18 November 2016)

All of these are available at www.tributum.com.ar/noticias/noticias/adj7906.pdf (accessed 18 November 2016)

This is referred to in Annex II, subsection (e), which refers to 'the transfer pricing report of Article 6'.

According to information provided by the AFIP for the CIAT 2013 transfer pricing report, documents and vouchers relating to transactions must be kept for at least ten years, and even for a longer period when they deal with transactions or acts whose knowledge may be essential for the determination of the tax base.

Available at http://infoleg.mecon.gov.ar/infoleglnternet/anexos/15000-19999/18771/texact.htm (accessed 18 November 2016)

115 All currency conversions in this paragraph are from www.xe.com/ 


\section{Appendix 3 Interviews held}

Natalia Mondino, Chief of the Department of International Information Management, International Tax Department, 18 February 2015.

Jose Deveikis, Internal Chief of the Strategic Management Division of International Tax, Department of International Technical Management and Evaluation, International Tax Department, 18 February 2015.

Graciela Liquin, Chief of the Area of International Tax Audit Support at the AFIP, 17 March 2015.

Sebastián Aguilera, Chief of the Area of International Tax Audit Support at the AFIP, 10 November 2015. 


\section{References}

Arceo, E. and De Lucchi, J.M. (2012) Estrategias de Desarrollo y Regímenes Legales para la Inversión Extranjera, Working Paper 43, Buenos Aires: CEFID-AR

Baistrocchi, E. (2012) 'Transfer Pricing Disputes in Argentina', in E. Baistrocchi (ed), Resolving Transfer Pricing Disputes: A Global Analysis, Cambridge Tax Law Series, Cambridge: Cambridge University Press: 669-727

Baistrocchi, E. (ed) (2011) Litigios de Precios de Transferencia: Teoría y Práctica, Buenos Aires: Abeledo Perrot

BDO (2012) Transfer Pricing News: Issue 10, September 2012, www.bdointernational.com (accessed 18 November 2016)

CIAT (2013) The Control of Transfer Pricing Manipulation in Latin America and the Caribbean, prepared within the framework of the International Tax Compact (ITC), funded by the German International Cooperation Agency (GIZ)

Corti, A.H.M. (2012) 'Algunas Reflexiones Sobre los Mecanismos de Exacción de la Renta Impositiva Nacional: A Propósito de las Ficciones de Contratos al Interior de los Conjuntos Económicos', Derecho Público Nro 2. Editorial Ministerio de Justicia y Derechos Humanos de la Nación, ISSN: 2250-7566, Year 1, Number 2

Corti, A.H.M. (2006) 'Algunas Ideas y Aportes para una Reforma Progresiva del Sistema Tributario Argentino' in Ideas para la Formulación de un Nuevo Contrato Social, Departamento de Publicaciones de la Facultad de Derecho de la Universidad de Buenos Aires: La Ley: 91-129

Corti, A.H.M. (1985) 'El Caso 'Kellogg' y el Restablecimiento de la Doctrina 'Parke Davis', 1985B, La Ley: 413-423

Cronista (2012) 'Jurisprudencia de la Cámara Nacional de Apelaciones en lo Contencioso Administrativo Federal', April 23, Cronista.com, www.cronista.com/fiscal/Resena-de-Jurisprudencia-Tributaria-20120423-0007.html (accessed 18 November 2016)

D’Agostino, H.M. (2010) Jurisprudencia Relevante en Materia de Operaciones Internacionales entre Partes Vinculadas: Anexo de Actualización, Colección Práctica Impuestos/Precios de Transferencia

Dai, R. (2012) International Accounting Databases on WRDS: Comparative Analysis, University of Pennsylvania: Wharton Research Data Services, http://wrdsweb.wharton.upenn.edu/wrds/research/applications/guides/pdf/March\%2016\%202012 \%20international.pdf (accessed 18 November 2016)

Echegaray, R. (Coord), Michel, G., Barzola, J.P. (2013) 'La Administración Tributaria Frente al Contribuyente Global: Aspectos Técnicos y Prácticos Relevantes', Buenos Aires: La Ley

EY (2014) 2014 Global Transfer Pricing Tax Authority Survey: Perspectives, Interpretations and Regulatory Change, www.ey.com/Publication/vwLUAssets/EY- 
global-transfer-pricing-tax-authority-survey/\$FILE/ey-2014-global-transfer-pricing-taxauthority-survey.pdf (accessed 18 November 2016)

Felitte, A. (2003) Parte II: Aspectos Prácticos de Fiscalización, el Control de los Precios de Transferencia; Tema 2, El Control de las Operaciones Internacionales, Administración Federal de Ingresos Públicos - AFIP, Argentina. Centro Interamericano de Administraciones Tributarias - CIAT, Conferencia Técnica Aspectos Claves en las Acciones de Control de las Administraciones Tributarias, Lisbon, Portugal, 29 September-2 October 2003.

Figueroa, A.H. (2014) 'Columna de Opinión: El Plan de Acción OCDE Contra la Erosión de la Base Imponible y el Traslado de los Beneficios. BEPS (Base Erosion and Profit Shifting)', Thomson Reuters, 7 October,

http://thomsonreuterslatam.com/articulos-de-opinion/07/10/2014/columna-de-opnion-elplan-de-accion-ocde-contra-la-erosion-de-la-base-imponible-y-el-traslado-de-losbeneficios-beps-base-erosion-and-profit-shifting\#sthash.YNaDBzph.dpuf (accessed 18 November 2016)

Figueroa, A. (2005) 'International Double Taxation: General Reflections on Jurisdictional Principles: Model Tax Conventions and Argentina's Experience', Bulletin For International Fiscal Documentation (IBDF), Special Issue IFA, 59th Congress, $59.8 / 9$

Gilardo, H. (2007) 'Fijan Alcance para Ganancias Obtenidas en el Exterior' Iprofesional, July 20, www.iprofesional.com/notas/50031-Fijan-alcance-paraganancias-obtenidas-en-el-exterior (accessed 18 November 2016)

Grondona, V. (2015) 'Transfer Pricing Manipulation and Capital Flight', from VI AEDA Congress: El Futuro del Desarrollo Argentino, Buenos Aires, 19-20 May 2015, www.aeda.org.ar/ (accessed 18 November 2016)

Grondona, V. (2014) La Manipulación de los Precios de Transferencia, Fuga de Capitales IV. Argentina, 2014, CEFID-AR Working Paper 58, supervised by Jorge Gaggero, Buenos Aires: CEFID-AR

Knightley, P. (1993) The Rise and Fall of the House of Vestey: The True Story of How Britain's Richest Family Beat the Taxman - And Came to Grief, London: Sphere

Laiun, F (2015) 'Los Gastos Efectuados en el Exterior y su Respaldo para ser Deducibles en el Impuesto a las Ganancias', Cronista.com, October 26, www.cronista.com/fiscal/Los-gastos-efectuados-en-el-exterior-y-su-respaldo-para-serdeducibles-en-el-Impuesto-a-las-Ganancias-20151026-0007.html (accessed 18 November 2016)

Martínez de Sucre, V., Corti, A.H.M. (1976) Multinacionales y Derecho, Colección Cuestionario, Buenos Aires: Ediciones de la Flor

OECD (2013) Foro Global sobre Transparencia e Intercambio de Informaciòn con Fines Tributarios, Informe de la Revisión de Pares: Argentina, 2012, Combinado: Fase 1 and Fase 2 (Spanish Version), Paris: OECD Publishing, http://dx.doi.org/10.1787/9789264202122-es

OECD (2010) Transfer Pricing Guidelines for Multinational Enterprises and Tax Administrations, Paris: OECD Publishing 
OECD (1995) Transfer Pricing Guidelines for Multinational Enterprises and Tax Administrations, Paris: OECD.

Olveira, D. (2015) ‘El Tribunal Fiscal Puso Límites al Traslado de Costos de Multis para Pagar Menos Ganancias', Cronista.com, July 28,

www.cronista.com/economiapolitica/El-Tribunal-Fiscal-puso-limites-al-traslado-decostos-de-multis-para-pagar-menos-Ganancias-20150728-0022.html (accessed 18 November 2016)

PwC (2012) International Transfer Pricing 2012, USA: PricewaterhouseCoopers LLP

Rua, M. B. (2014) Los 'Facilitadores' y sus Modos de Acción, Fuga de Capitales V. Argentina, 2014, CEFID-AR Working Paper 60, supervised by Jorge Gaggero, Buenos Aires: CEFID-AR

Soria, H. (2013) 'Las Principales Enseñanzas de los Distintos Fallos en Materia de Precios de Transferencia en la Argentina', Cronista.com, August 26, www.cronista.com/fiscal/Las-principales-enseanzas-de-los-distintos-fallosen-materiade-precios-de-transferencia-en-la-Argentina-20130826-0011.html (accessed 18 November 2016)

United Nations (2013) Practical Manual on Transfer Pricing for Developing Countries, Department of Economic and Social Affairs, New York: United Nations, www.un.org/esa/ffd/documents/UN_Manual_TransferPricing.pdf (accessed 18 November 2016) 


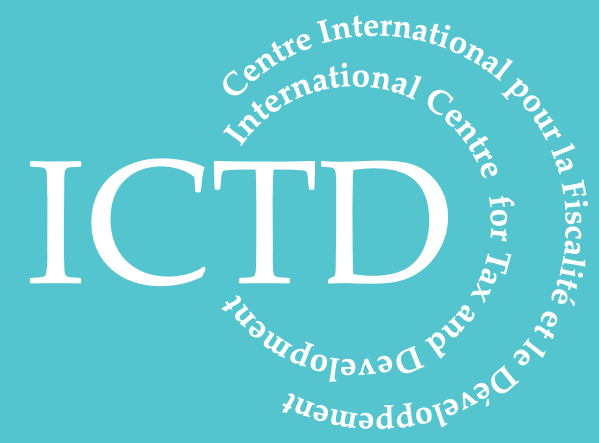

International Centre for Tax and Development at the Institute of Development Studies

Brighton BN1 9RE, UK

T: +44 (0) 1273606261

F: $+44(0) 1273621202$

E: info@ictd.ac

www.ictd.ac 